\title{
An Assessment of Mortgage Loan Default Propensity in Ghana
}

\begin{abstract}
Purpose: Credit market development requires appropriate credit assessment and default policies. This paper examines the impact of household characteristics on mortgage default using survey data collected from Ghanaian financial institutions.

Design/methodology/approach: Data was gathered using semi-structured questionnaires from customers of five universal banks in Ghana. A logistic regression was used to model the determinants of credit default propensity.

Findings: Contrary to established knowledge, the study shows that females are more likely to default on credit than their male counterparts. This is even more likely if the female is older, unmarried, divorced, financially illiterate and has lower educational attainments. These factors are associated with lower earning capacity, which increases default tendencies. The findings confirm that price instability (typified by excessive movements in inflation and exchange rates in addition to low national savings rate) are adversely linked to credit defaults. Borrower's perception of constraints to credit access (such as collateral requirements, interest rate and loan size) influence credit default. Banks should be encouraged to invest in the financial literacy skills development of their customers to mitigate credit default tendencies.
\end{abstract}

Practical/ social implications: The study is of practical value to credit officers and the development of the credit market in Ghana. A novel model is presented for assessing credit applications and developing credit default policies.

Originality/value: The research findings have not only expanded the frontiers of literature but also empirically examined the determinants of credit default propensity, which provides a basis for developing and improving credit default policy in the credit market.

Keywords: Customers, Default, Ghana, Low-income groups, Mortgage,

\section{INTRODUCTION}

Mortgage financing enable individuals and households with limited financial resources to access homeownership (Karanja, 2013) through the flow of funds to end users (Goodman and Ho, 2004; 
Karanja, 2013). Despite its recognized economic and social importance, mortgage finance remains under-developed in most developing countries. For instance, mortgage credit as a proportion of gross domestic product is less than 10 per cent in most developing economies such as Ghana, Nigeria, Egypt and Cameroon, but more the 50 per cent in developed economies such as the United States, United Kingdom, Netherlands, Sweden and Denmark (Badev et al., 2014). Existing empirical work attributes these wide variations to differences in creditor rights protection, credit information sharing and macroeconomic stability (Warnock and Warnock, 2008). Specifically, macroeconomic bottlenecks such as high and volatile inflation and high unemployment levels have been problematic in terms of pricing and affordability (Goodman and Ho, 2004; Karanja, 2013).

Existing studies also suggest an incompatibility between the conditions of low-income groups (LIG) and the requirements of formal housing financiers (Keys et al., 2014; Kamete, 2007). While LIG are rarely able to meet the stringent requirements for eligibility and loan terms, the financial institutions are unable to compromise and accommodate these groups since doing so would unnecessarily increase risks and jeopardize profitability (Skobba and Goetz, 2013). Investigations conducted by Akuffo (2006) suggest that the house price to affordability ratio in Ghana is 12 compared with 4 in developed countries. According to Tunstall et al. (2013), the middle-income group spend an average of 30 percent of their income on accommodation while the LIG spends 56 percent of income on accommodation.

Nwuba, et al. (2015) suggests that previous studies conducted in the UK (c.f. Barker, 2004), Australia (c.f. Australian Housing and Urban Research Institute, 2003) and New Zealand (c.f. Hargreaves, 2003), the USA (c.f. Gyourko and Linneman, 1993) and Nigeria (c.f. Chatterjee, 1982; Onyike, 2007) demonstrate that affordability constraints have increasingly limited access to homeownership for LIG. Higher real disposable income per person therefore increases the affordability of housing (Wolswijk, 2005) and reduces default tendencies. However, the literature concerning the impact of adverse trigger events, such as changing borrower characteristics (e.g. unemployment) is less well developed, particularly in developing economies. This is because an empirical evaluation of the impact of adverse trigger events on mortgage performance requires household-level data that can be linked to loan-level mortgage 
performance data. Such household-level trigger events data are however not widely available therefore, empirical research on mortgage default in developing economies remain an unchartered territory.

This paper examines the impact of household characteristics on mortgage default using survey data collected from financial institutions in Ghana. The remainder of the paper is divided into six sections. Section II reviews the literature concerning theory and empirical causes of mortgage default. Section III describes the data and methods used in the analysis. Section VI provides a descriptive analysis of household characteristics. Section V presents the econometric analysis based on a competing-risk framework. Section V1 presents implications for research and policy.

\section{MORTGAGE DEFAULT: THEORY AND EVIDENCE}

Mortgage default has been studied extensively due to its negative financial and social impacts upon society (c.f. Quigley and Van Order 1995; Epperson et al., 1992; Foster and Van Order 1984; Campbell and Dietrich 1983). There are two alternative views of home mortgage default behaviour - Equity theory and Ability-to-pay theory (Jackson and Kasserman, 1980). Recent studies incorporate trigger events (e.g. divorce, loss of a job, and accident or sudden death) to assess their influence upon default behaviour (c.f. Riddiough, 1991). However, previous empirical work has no firm conclusions about the relative importance of equity and affordability in mortgage default behaviour. While most literature finds the equity position to be the primary determinant in mortgage default decisions, some studies argue that non-equity effects (such as the source of income) are more significant (Wong et al., 2004).

\section{Equity Theory of Default}

The Equity theory of default hinges upon the idea that borrowers base their default decisions on a rational comparison of financial costs and returns involved in continuing or terminating mortgage payments. As rational agents, borrowers maximize their financial gains and minimize their financial loss. Borrowers attempt to maximise the equity position in the mortgaged property at each point of time. They cease to continue payments if the market value of the mortgaged property declines sufficiently to equal the outstanding mortgage loan balance at any time. Borrowers therefore refrain from loan default as long as income flows are sufficient to meet the 
periodic payment without undue financial burden. According to this theory, the measure of the equity position of borrowers - current loan-to-value (CLTV) ratio - is the most important factor in default decisions (Elul, 2006).

\section{Ability-to Pay-Theory of Default}

This theory, also known as the 'cash flow approach' suggests that when income flow remains sufficient to meet the periodic payment without undue financial burden, borrowers will refrain from defaulting on the loan. Contrary to the equity theory, the current debt servicing ratio (CDSR - defined as the monthly repayment obligations as a percentage of current monthly income) which captures the repayment capability of the borrower, plays a critical role in accounting for defaults (ibid). Whether default is triggered by on the basis of equity theory or the ability-to-pay theory, default can be treated as an option which is well established in the extant literature (cf. Campbell and Dietrich 1983; Foster and Van Order 1984; Epperson et al., 1992; Quigley and Van Order 1995).

\section{Option Theoretical Approach to Default and Evidence}

Since the 1980s, the Option theory has emerged as an important theoretical advance in the residential mortgage literature. An option is a contract in which one party obtains the right to buy or sell some underlying asset to another party for a pre-specified price, known as the 'strike' or 'exercise' price. When the party has the right to buy the asset at a fixed price, the contract is known as a call option; if the party has the right to sell the asset, it is known as a put option. Considering borrowers as welfare maximizers who actively evaluate different options to maximize their utility (pecuniary gain, borrowers should default on a mortgage when they have sufficient funds) whenever the value of the mortgage exceeds the value of the house. In this case, a borrower's ability to default on a mortgage becomes a put option.

Various empirical studies (in three strands of research investigation) have applied the option theory to mortgage defaults. The first strand encompasses those that indicate that a higher current loan-to-value ratio is associated with a higher risk of mortgage default (Capozza et al., 1998; Deng et al., 2000; Pennington-Cross and Ho, 2010; Goodman et al., 2010). Kau, et al., (1993) illustrated that the default probability is concave over time and that both higher current loan-to- 
value ratio and lower house value increase the default probability. The second strand argues that some mortgage defaults result from adverse triggers such as divorce and loss of employment (Ambrose and Capone, 1998; Capozza et al., 1998; Vandell and Thibodeau 1985; Vandell 1995; Capone 2002). While some studies show a positive association between higher rates of unemployment and elevated rates of default and foreclosure (cf. Capozza et al., 1997; Elmer and Seelig 1999, and Pennington-Cross and Ho 2010), others including a study by Deng et al. (2000) in the US find no statistically significant relationship for some key states like California and Texas (c.f. Clapp et al., 2001; Pennington-Cross and Chomsisengphet 2007; An et al., 2010; Ghent and Kudlyak 2011). Possible explanations for these contradictory findings may include differences in the data used, the time period considered and measurement of important variables.

The third strand encompasses 'events trigger-mortgage default' and suggests that negative equity is neither a necessary nor sufficient condition for mortgage default. In that case, considering very high loan loss severity for their loan sample, Lekkas et al. (1993) argue that even in the presence of significant negative equity, borrowers wait a long time before defaulting. Bhutta et al. (2010) for instance, found only very high levels of negative equity can trigger default for equity reasons. Thus, only a small fraction of 'underwater mortgages' end in foreclosure (Foote et al., 2008). Beside other factors such as the transaction costs of terminating a mortgage, Vandell (1995) suggests that trigger events like relocation, divorce, and job loss are vital determinants of mortgage termination. While Elul et al. (2010) suggests that the impact of illiquidity on mortgage default is comparable to that of the current loan-to-value ratio, Riley (2013) suggests that rather than equity fundamentals, liquidity constraints are more likely to trigger default among community reinvestment loan recipients.

Other research uses trigger event proxies to study mortgage defaults. Elmer and Seelig's theoretical model includes trigger events, insolvency and option-based financial incentives to show that insolvency is the primary motivation for default (Elmer and Seelig, 1999). Subsequently, in a study of evictions, repossessions and other housing finance difficulties of homeowners and renters in Britain, Boheim and Taylor (2000) illustrate that negative financial shocks are key triggers of eviction. Moreover, higher unemployment rates at the local level is associated with higher unemployment at the national level (Deng et al., 2000). More recently, 
Quercia et al., (2012) indicates that although both the structural and cyclical components of unemployment are associated with higher risk of default, the former at the local level is more relevant in predicting mortgage default.

\section{RESEARCH METHOD}

The study adopts a quantitative approach (Adams et al., 2007) involving deductive reasoning (Wilson, 2013; Patton, 2002). A field survey using a random administration of 120 closed-end structured questionnaires was undertaken to collect data from customers of five universal banks ADB, HFC, Stanbic, Fidelity and Ecobank; where the sample size was determined by the number of experts (with sufficient expertise) within each bank who could potentially participate in the study. These five banks were selected because they constitute some of the most popular banks in Ghana and were willing to participate in this study. Surveys are often associated with the deductive research approach and questionnaire administration (Saunders et al., 2009). The customers' questionnaire had three sections - namely: i) section A had questions related to clients' demography; ii) section $\mathrm{B}$ had questions on income level; and iii) section $\mathrm{C}$ had questions measuring mortgage default propensity (refer to Table 1). 100 responses were received constituting a $83.33 \%$ response rate and indicating the level of support given from these five banks.

$<$ Insert Table 1 about here $>$

\section{Modelling Mortgage Loan Default Propensity}

The logistics regression method is applied because it is particularly suitable for empirical studies with qualitative data, which considers the loan status as a binary (or Boolean) variable that takes a value of either zero (for mortgages that are performing) or one (for non-performing mortgages). A logistic model formulates the probability of a loan being non-performing as a logistic function of some combination of explanatory variables as follows:

$$
\left.P(\text { loan status }=1)=1 / 1+e^{-\left(\alpha+\beta_{1} X_{1}+\beta_{2} X_{2}+\cdots\right.} \beta_{k} X_{k}\right)
$$


where $P($ loan status $=1)$ is the probability of a mortgage being non-performing, $X_{1}, X_{2}, \ldots X_{k}$ are explanatory variables, factors or predictors that may help determine default risk; $\alpha$ is a constant; $\beta_{1}, \beta_{2}, \ldots, \beta_{k}$ are coefficients that capture the impact that each factor may have on default risk; and $\varepsilon$ is an error term, which is assumed to be independent and normally distributed. Kleinbaum et al. (2008) indicate that logistic regression quantifies the relationship between the dichotomous dependent variable and the predictors using odds ratios. Odds ratios are the probability that an event will occur divided by the probability that the event will not happen. The odds ratio in this study is the probability that a borrower will default on a mortgage loan payment obligation divided by the probability that a borrower will not default on a mortgage loan payment obligation. Odds are calculated using the formula:

$$
\begin{aligned}
\text { Odds } & =\mathrm{P}(\text { case }) / \mathrm{P}(\text { non-case }) \\
& =\mathrm{P}(\mathrm{X}) / 1-\mathrm{P}(\mathrm{X}) \\
& =\left[\exp \left(-\mathrm{X}^{\mathrm{T}} \beta\right)\right]^{-1}
\end{aligned}
$$

Where, $\mathrm{P}(\mathrm{X})$ is the probability of success (case) and $1-\mathrm{P}(\mathrm{X})$ is the probability of failure (non case). The odds ratio, which is meant to indicate whether the odds of a success (case) are equally likely to the odds of failure is given by:

$$
\text { Odds }=\text { Odds of cases } / \text { Odds of non-cases }
$$

An odds ratio of one is an indication that the odds of a success (case) outcome are equally likely for to the odds of a failure (non-case). The odds ratio has a minimum value of zero but have no upper limit. A value less than one indicates that the case is not likely to prevail under those circumstances and a value greater than one indicates a high likelihood for belonging to the group. The further the odds ratio is from one, the stronger the relationship. Rearranging, the resultant will be:

$$
\mathrm{P}(\mathrm{X}) / 1-\mathrm{P}(\mathrm{X})=\left[\exp \left(-\mathrm{X}^{\mathrm{T}} \beta\right)\right]^{-1}
$$

Taking the natural logarithm of both sides: 


$$
\begin{gathered}
\ln [\mathrm{P}(\mathrm{X}) / 1-\mathrm{P}(\mathrm{X})]=-\left(-\mathrm{X}^{\mathrm{T}} \beta\right) \\
=\mathrm{X}^{\mathrm{T}} \beta \\
\ln (\text { Odds })=\operatorname{logit}(\mathrm{y}) \\
=\ln [\mathrm{P}(\mathrm{X}) / 1-\mathrm{P}(\mathrm{X})]
\end{gathered}
$$

Where, logit(y) is the natural logarithm of the odds of outcome. The coefficients $\beta=\left[\beta_{0}, \beta_{1}\right.$, $\left.\beta_{2}, \cdots \beta_{k}\right]$ are estimated using the maximum likelihood method:

$$
\mathrm{G}(\mathrm{X})=\ln [\mathrm{P}(\mathrm{X}) / 1-\mathrm{P}(\mathrm{X})]=\left(\mathrm{X}^{\mathrm{T}} \beta\right)
$$

The transformation $\mathrm{G}(\mathrm{X})$ is referred to as the logit transformation (Al-Ghamdi, 2001).

\section{INITIAL ASSESSMENTS AND RESULTS}

According to Asiedu and Alfen (2016) background knowledge about the respondents to a survey, helps to assess the reliability and integrity of the data received and to generate confidence and credibility in the results. Tables 2 and 3 reports upon demographic characteristics of the respondents. The results indicate that the majority of respondents were male. Barber and Odean (2001) reveal that, males often exhibit more confidence than females, which explains that gender is worth investigating when studying mortgage choices. Besides, other studies illustrate that females are more risk averse, and that explains their reluctance in taking mortgage facilities (Borghans et al., 2009; Harris et al., 2006; Dohmen et al., 2011).

$$
\begin{aligned}
& <\text { Insert Table } 2 \text { about here> } \\
& <\text { Insert Table } 3 \text { about here> }
\end{aligned}
$$

Similarly, the results show that 66 per cent of the respondents were married. This is intuitive given that those who have settled down often plan for permanent homes. This corroborates the observation of Finke et al. (2005) who found that households with co-borrowers (e.g. conjugal partners) and short expected housing tenures increases the propensity of applying for a mortgage facility. With respect to the level of education of respondents, 76 per cent had a minimum of first degree. According to Campbell (2006), mortgage refinancing is less successfully purchased by 
households with a low educational level. Again, their high educational levels guarantee the respondents' understanding of the survey and enhanced credibility. The results on income levels shows that the majority (54 per cent) of respondents earn above US\$ 500 per month. Fortowsky et al. (2009) observed that higher income levels of borrowers increases the likelihood of taking a mortgage facility.

\section{Mortgage Default Propensity: Baseline Results}

Results predicting four measures of default propensity are reported in Table 4. Models one (M1) and two (M2) predict borrowers' previous challenges when repaying any loan and actual default on the repayment of any loan respectively. Models three (M3) and four (M4) specifically measure borrowers' previous challenges repaying a mortgage and their actual default on mortgage repayment accordingly. Only demographic variables were used in the baseline estimations. The results suggest that household size, first degree holders, self-employed borrowers and private sector workers are generally negatively correlated with mortgage default propensity. In other words, these variables reduce the propensity of mortgage default. However, only household size, self-employed borrowers and private sector employees enter the regression significantly. Self-employed borrowers and private sector employees are strong and significant variables of mortgage default propensity at $p=0.05$. Household size is relevant in predicting previous challenges in repaying mortgages and previous mortgage defaults at $p=0.10$ and 0.05 significance levels. Household size is however not significant in determining previous challenges in repaying other loan types and previous defaults on other loans. Working in the private sector is also not a significant factor in predicting actual defaults on other loan types.

\section{$<$ Insert Table 4 about here $>$}

On the contrary, age, Higher National Diploma holders, females and unmarried (single) borrowers are positively associated with mortgage defaults. However, females are only significant in predicting previous challenges in other loan repayment and actual defaults of other loans, and not mortgages. With the exception of actual defaults on other loans, unmarried (single) borrowers are powerfully and significantly associated with previous challenges in repaying other loans and mortgages as well as defaulting on mortgage repayments. Age is only significant in predicting both previous challenges in repaying other loans and mortgages. Being 
female is significantly associated with previous challenges in repaying other loans and defaults on other loans but not mortgages. Holding a Higher National Diploma is consistently insignificant with the direction of the relationship changing depending on the variable predicted.

The baseline results further suggest that females are more likely to face challenges in repaying other loans and default on other loans than males. Self-employed and private sector employees are less likely to face challenges in repaying other loans and mortgages, and default on other loans and mortgages when compared with public sector employees. Unmarried borrowers are more likely to face challenges in repaying other loans and mortgages, and default on mortgages than married borrowers. The baseline models are improved by incorporating five categories of additional variables. Financial literacy (refer to Tables 5-8) affects the likelihood of mortgage default. Two variables - savings and budgeting - are used as proxies for financial literacy. Savings could serve as emergency funds for unplanned expenditures and expenses. The savings dimension is defined by four questions bordering on borrowers' knowledge and ownership of an emergency fund such as a savings account and their ability to calculate the interest accruing to their accounts. The budget dimension measures borrower's ability to set up a personal budget and to track various components such as expenditures. This dimension also explores borrowers' budgetary allocations to basic needs like food, housing and clothing.

Measures of risk tolerance are also included in the models. The risk tolerance level of borrowers is measured by their response to a question about how they perceive themselves in relation to risk and return profiles of investments. A scale measuring risk tolerance levels ranging from one to four is used in this regard (representing the most risk averse and the most risk tolerant borrowers respectively).

\footnotetext{
$<$ Insert Table 5 about here>

$<$ Insert Table 6 about here>

$<$ Insert Table 7 about here $>$

$<$ Insert Table 8 about here $>$
} 
To deal with multicollinearity, the 11 variables measuring financial literacy and the 1 variable measuring risk tolerance are alternatively included in model. The results indicate that savings and budgetary proxies for financial literacy are significantly associated with the likelihood of mortgage default. This is however not the case in explaining defaults on other types of loans (with the exception of budgetary allocations to clothing). Most of the savings and budgetary proxies are positively correlated with the likelihood of mortgage default. In terms of explaining previous challenges in repaying other types of loans, budgetary allocations to food and housing are negatively linked but insignificant. Similarly, two savings proxies namely, ownerships of an emergency fund and knowledge of how to calculate interest rates are not relevant in predicting previous challenges in repaying other loans. The relationship between some of the variables, for instance, ownership of an emergency fund and the likelihood of mortgage default alternate in terms of direction of effect depending upon the variable used in measuring mortgage default. So, contrary to the likelihood of mortgage default in terms of previous challenges in repaying other loans, the relationship between ownership of an emergency fund and default on other loans turns negative.

The next set of regressions incorporates seven macroeconomic measures and three measures of borrowers' perception of the main constraints to accessing mortgage finance (refer to Tables 9 to 12). Again, the direction of the relationship between the macroeconomic variables and the likelihood of mortgage default alternates in relation to the indicator used. The results show that most of the variables are not statistically relevant. Only the national savings rate and the exchange rate enters significantly in explaining previous challenges in repaying other loans and mortgages respectively. Besides national savings rate and exchange rate, inflation rate is also relevant in predicting default on mortgage loans. All the three measures of the perceived constraints to mortgage access are consistently positive and significant in predicting most of the indicators of mortgage default likelihood. The only exception is in relation to explaining defaults on other loans.

\footnotetext{
$<<$ INSERT TABLE 9 HERE $>>$

$<<$ INSERT TABLE 10 HERE $>>$

$<<$ INSERT TABLE 11 HERE $>>$
} 


\section{$<<$ INSERT TABLE 12 HERE $>>$}

\section{DISCUSSION}

The logistics regression analyses show that demographic characteristics of borrowers, their level of financial literacy, perception of macroeconomic performance, risk tolerance level and the constraints borrowers' face in accessing mortgages are associated with the likelihood of mortgage default in different directions and magnitudes.

\section{Demographics for Credit Default}

The study found that gender, age, and the sector in which a borrower works are major determinant of loan default. Older unmarried females who work in the public sector are more likely to default on credit facilities than their younger male and female counterparts. Demographic-differences with respect to credit repayment-rates are a long-standing debate. Particularly, gender-differences have been highlighted in extant literature (Borghans et al., 2009; Harris et al., 2006; Dohmen et al., 2011; Weber et al., 2002; Lundeberg et al. 1994). Contrary to our findings, men are traditionally more likely to default on credit facilities (Jianakoplos and Bernasek, 1998). This is because men generally take more risk that could lead to them to default on a credit facility. Men tend to accumulate more debt than women and default on mortgages more often (Khandker et. al. 1995; Hulme 1991; Kevane and Wydick 2001). Further, older people are usually more responsible and have relatively higher incomes than younger people and hence, are less likely to default (Thomas, 2000; Boyle et. al. 1992)

However, these findings can be best understood when reference is provided to general facts that are internationally accepted and the Ghanaian context. Internationally, women earn less than men (Blau and Kahn, 1996) and thus, reduce their relative ability to afford credit. Low incomes may be due to low educational attainments, which is positively associated with credit defaults according to this study. Higher National Diploma (HND) holders are more likely to default than degree holders. In addition, where a person works in terms of sector determines their earning capacity. Private sector employees generally earn more because private sector firms are often more productive and more likely to pay more to retain a productive employee who is likely to have higher educational attainments. Therefore, it is possible that most of the females surveyed 
have lower educational attainments (HND holders), work in the public sector and earn less which in turn increases their likelihood to default on credit. This situation may be compounded if the females are single parents with responsibilities towards not only their immediate nuclear family (children) but also the extended family.

The result is however consistent with the view that the marital status of the borrower is a relevant determinant of the likelihood to default. Between married and single people (including divorced people), the latter has a higher chance of defaulting. This could be due to the fact that married people are usually more responsible than single people, particularly in terms of nuclear family responsibilities. These responsibilities are likely to deter them from opportunistic behaviours that could result in credit default, and in the case of mortgage default, could result in the loss of their homes with varying social consequences. These responsibilities and ramifications if not honoured therefore, serve as a discipline device that mitigates credit defaults.

\section{Financial Literacy and Credit Default}

Financial literacy is also a major determinant of credit default. Although general literacy level is high in Ghana, financial literacy is low. Boamah (2011) indicates that only 20 per cent of the Ghanaian population is bankable; out of which only 10 per cent have bank accounts. Further, less than 10 percentage of the population can afford to have a mortgage loan. In effect, the majority of Ghanaians are not used to regular debt servicing obligations (Karley, 2002; Ansah, 1996). Therefore, financially literate borrowers who have savings accounts possess corporate finance skills (such as the ability to calculate interests earned on investments and budgeting skills) have comparatively lower chances of defaulting than those who lack these characteristics (French and McKillop, 2014). Besides facilitating a better understanding of credit obligations, higher educational attainments are also correlated with a borrower's savings behaviour and budgeting skills, which are important money management skills.

\section{Macroeconomic Instability and Credit Default}

The study confirms earlier studies that establish a link between macroeconomic instability and credit market development. A low national savings rate and price instability, typified by excessive movements in exchange rate and inflation, are relevant drivers of credit default. It is 
well established that macroeconomic instability heightens the perceive risk of default and thus distorts price signals. This results in high inflation risk and interest rate risk premiums that increase interest rates and exacerbate credit affordability, which increases default. Historically, Ghana's macroeconomic environment has been characterised by high fluctuations in gross domestic product and exchange rates, high inflation rate and interest rates (Boamah, 2012). The 1990 s for instance were typical of these characteristics with inflation rising up to 70 per cent and interest rates about 40 per cent. Consequently, only a few rich or highly paid workers could access credit. It is also one of the reasons that discourage commercial banks from participating in the mortgage market, hence its under-developed nature.

\section{Credit Access Constraints and Default}

It is well known that high and volatile interest rates, high collateral requirements and loan size are some of the constraints to accessing credit facilities. In this study, the borrower' perceptions about these factors as constraints to credit access are shown to be major predictors of credit default. As indicated above, high and volatile interest rates increase default tendencies in an economy that is characterised by low-income levels. Collateral is an alternative instrument to information for signalling borrower quality and internalizing externalities like losses due to default. So, it is normal that collateral requirements are high in a highly information asymmetric environment such as the Ghanaian economy. Further, average house prices in Ghana are expensive and require large loan amounts that are beyond the reach of most people. Thus, large loan amounts of finance are associated with higher chances of default.

\section{CONCLUSION}

This study has assessed the determinants of the propensity of credit default using survey data from Ghana. The data was collected from customers of four commercial banks using semistructured questionnaires. Using logistics regression analysis, the study shows that demographic and financial factors as well as borrowers' perception about the macroeconomic and constraints to credit access are major determinants of credit default propensity. In particular, unmarried older females workers in the public sector with lower education attainments are more prone to credit default than their younger female and male counterparts, who are married and more educated. Also, savings and budgetary ability proxies for financial literacy are powerfully 
associated with credit default. Higher levels of financial literacy are shown to reduce a borrower's chances of defaulting. Macroeconomic factors like inflation, exchange rate and national savings rate are relevant in explaining borrower default behaviour. These findings are important for two main reasons. First, the study is of theoretical value and adds to the extant literature. For instance, contrary to established wisdom, females were found to be more likely to default given low educational attainments, been unmarried and possibly earning a low income. Second, the study is of practical value to credit officers and the development of the credit market in Ghana. The research is however limited to those banks studied and further research could expand the study to include many more commercial banks. 


\section{REFERENCES}

Adams, J., Khan, T.A., Raeside, R. and White, D. (2007) Research methods for graduate business and social science students. Sage: London. ISBN 9780761935896.

Akuffo, A. (2006) HFC'S pioneering role and rational for conversion to full banking activities: sustainability of specialised lenders. The World Bank/International Finance Corporation (IFC), Housing Finance Conference, 16-17 March, Washington DC, USA.

Ambrose, B.W. and Capone, C.A. (1998) Modeling the conditional probability of foreclosure in the context of single-family mortgage default resolutions, Real Estate Economics, Vol. 26 No. 3, pp. 391-429. https://doi.org/10.1111/1540-6229.00751.

An, X., Clapp, J.C., and Deng Y. (2010) Omitted mobility characteristics and property market dynamics: application to mortgage termination, Journal of Real Estate Finance and Economics Vol. 41, No. 3, pp. 245-271. https://doi.org/10.2139/ssrn.803525.

Ansah, B.S. (1996) The home finance company limited in Ghana, West Africa, Housing Finance International, Vol. 10, No. 4, pp. 15-20.

Asiedu, R. O., and Alfen, H. W. (2016) Understanding the underlying reasons behind time overruns of government building projects in Ghana, KSCE, Journal of Civil Engineering, Vol. 20, No. 6, pp. 2103-2111. https://doi.org/10.1007/s12205-015-0544-4.

Australian Housing and Urban Research Institute (2003) Housing aspirations of Australian households, Queensland Research Center and Swinburne-Monash Research Center. AHURI Final Report No. 30. ISBN: 1920758186.

Badev, A., Thorsten B., Ligia, V., and Walley, S. (2014) Housing finance across countries: new data and analysis, Policy Research Working Paper; No. 6756. World Bank, Washington DC. https://openknowledge.worldbank.org/handle/10986/16821 License: CC BY 3.0 IGO. https://doi.org/10.1596/1813-9450-6756.

Barber, B. M., and Odean, T. (2001) Boys will be boys: Gender, overconfidence, and common stock investment. The Quarterly Journal of Economics, Vol. 116, No. 1, pp. 261-292. https://doi.org/10.1162/003355301556400.

Barker, K. (2004) Review of housing supply. Delivering security: securing our future housing needs, Final Report - Recommendations, available at: http://image.guardian.co.uk/ sys files/Guardian/documents/2004/03/17/Barker.pdf (accessed 4 January 2011).

Bhutta, Neil, Jane Dokko, and Hui Shan, (2010) The depth of negative equity and mortgage default decisions, Finance and Economics Discussion Series No. 2010-35, Federal Reserve Board. Available from: http://www.federalreserve.gov/pubs/feds/2010/201035/201035pap.pdf

Blau, F. D. and Kahn, L. M. (1996) Wage structure and gender earnings differentials: an international comparison, Economica, Vol. 63, No. 250, pp. S29-S62. https://doi.org/10.2307/2554808.

Boamah, N. A. (2011) The macro-economy and housing credit market in Ghana, African Research Review, Vol. 5, No. 1. pp. 25-39. https://doi.org/10.4314/afrrev.v5i1.64507. 
Boamah, N. A. (2012) Housing for the vulnerable in the Offinso South Municipality of Ghana, Housing, Care and Support, Vol. 15, No. 3, pp. 140-147. https://doi.org/10.1108/14608791211268572.

Boheim, R. and Taylor, M. (2000) My Home was my castle: evictions and repossessions in Britain, Journal of Housing Economics, Vol. 9, No. 4, pp. 287-319. https://doi.org/10.1006/jhec.2001.0271

Borghans, L., Golsteyn, B., Heckman, J. and Meijers, H. (2009) Gender differences in risk aversion and ambiguity aversion, Journal of the European Economic Association, Vol. 7, No. 2-3, pp 649-658. https://doi.org/10.3386/w14713

Boyle, M., Crook J.N., Hamilton, R., and Thomas L.C., (1992) Methods for credit scoring applied to slow payers in credit scoring and credit control, Oxford University Press: Oxford, pp. 75-90.

Campbell, J. (2006) Household finance, Journal of Finance, Vol. 61, No. 4, pp. 1553-1604. https://doi.org/10.3386/w12149

Campbell T. S., and Dietrich J. K., (1983) The determinants of default on insured conventional residential mortgage loans, The Journal of Finance, Vol. 38, No. 5, pp. 1569-1581. https://doi.org/10.2307/2327587

Capone, C., (2002) Research into mortgage default and affordable housing - a primer, Congressional Budget Office, Washington D.C. Available from: http://www.liscnet.org.

Capozza, D.R., Kazarian, D. and Thomson, T.A., (1997) Mortgage default in local markets', Real Estate Economics, Vol. 25, No. 4, pp. 631-55. https://doi.org/10.1111/1540-6229.00731.

Capozza, D.R., Kazarian, D. and Thomson, T.A. (1998) The conditional probability of mortgage default, Real Estate Economics, Vol. 26 No. 3, pp. 359-89. https://doi.org/10.111/15406229.00750 .

Chatterjee, L.R., (1982) Effective targeting for basic shelter provision, Economic Geography, Vol. 58 No. 1, pp. 62-74. https://doi.org/10.2307/143620

Clapp, J. M., Goldberg, G. M., Harding, J. P. and LaCour-Little, M. (2001) Movers and shuckers: interdependent prepayment decisions, Real Estate Economics, Vol. 29, No. 3, pp. 411-450. https://doi.org/10.1111/1080-8620.00017.

Deng, Y., Quigley, J. M., and Van Order, R. (2000) Mortgage terminations, heterogeneity and the exercise of mortgage options, Econometrica, Vol. 68, No. 2, pp. 275-307. https://doi.org/10.2139/ssrn.156828.

Dohmen, T. J., Falk, A., Huffman, D., Sunde, U., Schupp, J., and Wagner, G. G. (2011) individual risk attitudes: measurement, determinants, and behavioural consequences, Journal of European Economic Association, Vol. 9, No. 3, pp. 522-550. https://doi.org/10.1111/j.1542-4774.2011.01.015.x.

Elmer, P. J., and Seelig, S. A., (1999) Insolvency, trigger events, and consumer risk posture in the theory of single-family mortgage default, Journal of Housing Research, Vol. 10, No. 1, pp. 1-25. https://doi.org/10.2139/ssrn.126168 
Elul, R. (2006) Residential mortgage default, Federal Reserve Bank of Philadelphia Business Review, Third Quarter, pp 21-30.

Elul, R., Souleles, N. S., Chomsisengphet, S., Glennon, D., and Hunt, R. (2010) What 'triggers' mortgage default?, American Economic Review, Vol. 100, No. 2, pp. 490-494. https://doi.org/10.1257/aer.100.2.490.

Epperson, J. F., Kau, J. B., Keenan D. C., and Muller, W. J. (1992) A generalized valuation model for fixed-rate residential mortgages, Journal of Money, Credit and Banking, Vol. 24, No. 3, pp. 279-299. https://doi.org/10.2307/1992718.

Finke, M., Huston, S., Siman, E., and Corlija, M. (2005) Characteristics of recent adjustable-rate mortgage borrowers, Financial Counselling and Planning, Vol. 16, No. 2, pp. 17-28.

Foster, C., and Van Order, R. (1984) An option-based model of mortgage default, Housing Finance Review, Vol. 3, No. 4, pp. 351-72.

Foote, C., Gerardi, K. and Willen, P. (2008) Negative equity and foreclosure: theory and evidence, Journal of Urban Economics, Vol. 6, No. 2, pp. 234.245. https://doi.org/10.2139/ssrn.1153413.

Fortowsky, E., LaCour-Little, M., Rosenblatt, E.8 and Yao, V. (2009) Housing tenure and mortgage choice, Journal of Real Estate Finance \& Economics, Vol. 42, No. 2, pp. $162-$ 180. https://doi.org/10.1007/s11146-009-9193-z.

French, D. and D. G. McKillop (2014) Financial literacy and over-indebtedness in low-income households. ssrn id:2505084.

Ghent, A. C., and Kudlyak, M. (2011) Recourse and residential mortgage default: evidence from U.S. States, Review of Financial Studies, Vol. 24, No. 9, pp. 3139-3186. https://doi.org/10.1093/rfs/hhr055.

Goodman, L. S., and Ho, J. (2004) Measuring the mortgage market's convexity needs, The Journal of Fixed Income, Vol. 14, No. 2, pp. 6-19. https://doi.org/10.3905/jfi.2004.439833.

Goodman, L. R, Ashworth, B. L., and Yin, K. (2010) Second liens: how important?, Journal of Fixed Income, Vol. 20, No. 2, pp. 19-30. https://doi.org/10.3905/jfi.2010.20.2.019.

Gyourko, J. and Linneman, P. (1993) The affordability of the American dream: an examination of the last 30 years, Journal of Housing Research, Vol. 4 ,No. 1, pp. 39-72.

Hargreaves, B. (2003a) Home ownership - an increasingly elusive goal, paper presented at Pacific Rim Real Estate Society (PRRES) Conference, Brisbane, 19-22 January.

Harris, C. R., Jenkins, M., and Glaser, D. (2006) Gender differences in risk assessment: why do women take fewer risks than men?, Judgment and Decision Making, Vol. 1, No. 1, pp. 48-63.

Hulme, D. (1991) The Malawi Mudzi Fund: Daughter of Grameen, Journal of International Development, Vol. 3, No. 3, pp. 427-431. https://doi.org/10.1002/jid.4010030315.

Jackson, J. R. and Kasserman, D. L. (1980) Default risk on home mortgage loans: a test of competing hypotheses, The Journal of Risk and Insurance, Vol. 47, No. 4, pp. 678. https://doi.org/10.2307/252290. 
Jianakoplos, N. A., and Bernasek, A. (1998) Are women more risk averse?, Economic Inquiry, Vol. 36, No. 4, pp. 620-30. https://doi.org/10.1111/j.1465-7295.1998.tb01740.x.

Kamete, A. Y. (2007) Cold-hearted, negligent and spineless? Planning, planners and the (r) ejection of "filth" in urban Zimbabwe. International Planning Studies, Vol. 12, No. 2, pp. 153-171. https://doi.org/10.1080/13563470701477959.

Karanja, A. W. (2013) Mortgage financing and profitability of commercial banks in Kenya (Doctoral dissertation, KENYATTA UNIVERSITY).

Karley, N. K. (2002)Alternative options to mortgages in Ghana, Housing Finance International, Vol. 17, No. 2, pp. 26-30.

Kau, J. B., Keenan, D. C. and Kim, T. (1993) Transaction costs, suboptimal termination, and default probabilities for mortgages, AREUEA Journal, Vol. 21, No. 3, pp. 247-63. https://doi.org/10.1111/1540-6229.00610.

Kevane, M. and Wydick, B. (2001) Microenterprise lending to female entrepreneurs: sacrificing economic growth for poverty alleviation?, World Development, Vol. 29, No. 7, pp. 12251236. https://doi.org/10.1016/S0305-750X(01)00032-8

Keys, B. J., Piskorski, T., Seru, A., and Yao, V. (2014) Mortgage rates, household balance sheets, and the real economy (No. w20561). National Bureau of Economic Research.

Khandker, S.R., Khalily, B., and Kahn, Z., (1995) Grameen Bank: performance and sustainability, World Bank Discussion Paper 306, Washington DC.

Lekkas, V., Quigley, J. M., and Van Order, R. (1993) Loan loss severity and optimal mortgage default, AREUEA Journal, Vol. 21, No. 4, pp. 353-372. https://doi.org/10.1111/15406229.00616

Lundeberg, M. A., Fox, P. W., and Punccohar, J. (1994) Highly confident but wrong: gender differences and similarities in confidence judgements, Journal of Educational Psychology, Vol. 86, No. 1, pp. 114-121. https://doi.org/10.1037//0022-0663.86.1.114.

Nwuba, C. C., Kalu, I. U., and Umeh, J. A. (2015) Determinants of homeownership affordability in Nigeria's urban housing markets, International Journal of Housing Markets and Analysis, Vol. 8, No. 2, pp. 189-206. https://doi.org/10.1108/ijhma-06-2014-0020.

Onyike, J.A (2007) Addressing the urban housing problems of Nigeria in the 21 st century. Retrieved May 20, 2012 from http://asa.docs.blogspot.com/2011/10/addressing-urbanHousing-problems- of.html.ASA Journals

Patton, M.Q. (2002) Qualitative research and evaluation methods (3 ${ }^{\text {rd }}$ Ed.). London: Sage Publication.

Pennington-Cross, A., and Ho, G. (2010) The termination of subprime hybrid and fixed-rate mortgages, Real Estate Economics, Vol. 38, No. 3, pp. 399-426. https://doi.org/10.1111/j.1540-6229.2010.00271.x.

Pennington-Cross, A., and Chomsisengphet, S. (2007) Subprime refinancing: equity extraction and mortgage termination, Real Estate Economics, Vol. 35, No. 2, pp.233-263. https://doi.org/10.111/j.1540-6229.2007.00189.x. 
Quercia, R. G., Pennington-Cross, A., and Yue Tian, C. (2012) Mortgage default and prepayment risks among moderate-and low-income households, Real Estate Economics, Vol. 40, pp. S159-S198. https://doi.org/10.1111/j.1540-6229.2012.00350.x.

Quigley, J. M., and Van Order, R. (1995)" Explicit test of contingent claims models of mortgage default, Journal of Real Estate Finance and Economics, Vol. 1, No. 2, pp. 99-117. https://doi.org/10.1007/bf01098656.

Riddiough, T.J. (1991) Equilibrium mortgage default pricing with non-optimal borrower behaviour, University of Wisconsin Ph.D diss.

Riley, S. F. (2013) Strategic default behaviour and attitudes among low-income homeowners, (February 1). http://papers.ssrn.com/abstract=2282518.

Saunders, M., Lewis, P. and Thornhill, A. (2009) Research methods for business students $\left(5^{\text {th }}\right.$ Ed.). London: Prentice Hall. ISBN:978-0-273-71686-0.

Skobba, K., and Goetz, E. G. (2013). Mobility decisions of very low-income households. Cityscape, pp. 155-171.

Thomas, L. C. (2000) A survey of credit and behavioural scoring: forecasting financial risk of lending of consumers, International Journal of Forecasting, Vol. 16, No. 2, pp. 149-172.

Tunstall, R., Bevan, M., Bradshaw, J., Croucher, K., Duffy, S., Hunter, C., Jones, A., Rugg, J., Wallace, A. and Wilcox, S. (2013) The links between housing and poverty: an evidence review, Joseph Rowntree Foundation, Report.

Vandell, K. (1995) How ruthless is mortgage default?, Journal of Housing Research, Vol. 6, No. 2, pp. 245-264.

Vandell, K.D. and Thibodeau, T. (1985) Estimation of mortgage defaults using disaggregate loan history data, Journal of the American Estate and Urban Economics Association, Vol. 13, No. 3, pp. 292-316. https://doi.org/10.1111/1540-6229.00356.

Warnock, V. C. and Warnock, F. E. (2008) Markets and housing finance, Journal of Housing Economics, Vol. 17, No. 3, pp. 239-251. https://doi.org/10.1016/j.jhe.2008.03.001.

Weber, E.U., Blais, A.R. and Betz, N.E. (2002) A domain-specific risk-attitude scale: measuring risk perceptions and risk behaviors, Journal of Behavioral Decision Making, Vol. 15, No. 4, pp. 263-290. https://doi.org/10.1002/bdm.414.

Wilson, J. (2013) Essentials of business research: A guide to doing your research project $\left(2^{\text {nd }}\right.$ Ed.). Washington DC: Sage publications.

Wolswijk, G. (2005) Some fiscal effects on mortgage debt growth in the EU, European Central Bank Working Paper, No. 526. http://www.ecb.int ISSN 1725-2806.

Wong, E., Fung, L., Fong, T., and Sze, A. (2004) Residential mortgage default risk and loan-tovalue ratio, Hong Kong Monetary Authority Quarterly Bulletin 41. Hong Kong, China: Hong Kong Monetary Authority. 
Table 1 - Label Variables and Definitions

\begin{tabular}{|c|c|c|}
\hline Construct & Variable & Variable Definition \\
\hline \multirow{5}{*}{$\begin{array}{l}\text { Default risk } \\
\text { (Dependent } \\
\text { variable) }\end{array}$} & & $\begin{array}{l}\text { Dummy }=1 \text { if the borrower has ever had a challenge repaying any loan facility, } \\
\text { and } 0 \text { if otherwise }\end{array}$ \\
\hline & & $\begin{array}{l}\text { Dummy }=1 \text { if the borrower has Have ever defaulted on a loan facility, or } 0 \text { if } \\
\text { otherwise }\end{array}$ \\
\hline & & $\begin{array}{l}\text { Dummy }=1 \text { if the borrower has any challenge repaying his/her mortgage, or } 0 \text { if } \\
\text { otherwise }\end{array}$ \\
\hline & & $\begin{array}{l}\text { Dummy }=1 \text { if borrower has ever missed any monthly payment of mortgage, or } 0 \\
\text { if otherwise }\end{array}$ \\
\hline & & $\begin{array}{l}\text { Dummy }=1 \text { if borrower thinks he/she could fully complete payment of mortgage, } \\
\text { or } 0 \text { if otherwise }\end{array}$ \\
\hline \multirow{6}{*}{ Demographics } & Gender & Dummy $=1$ if male, and 0 if female \\
\hline & $\begin{array}{l}\text { Education } \\
\text { level }\end{array}$ & $\begin{array}{l}\text { Dummy }=1 \text { if } 1^{\text {st }} \text { degree holder, and } 0 \text { if } 2^{\text {nd }} \text { and } 3^{\text {rd }} \text { degree holder, HND holder, } \\
\text { SHS leaver; } 1 \text { if } 2^{\text {nd }} \text { degree holder, and } 0 \text { if } 1^{\text {st }} \text { degree holder, HND holder, SHS } \\
\text { leaver }\end{array}$ \\
\hline & $\begin{array}{l}\text { Employment } \\
\text { status }\end{array}$ & $\begin{array}{l}\text { Dummy }=1 \text { if employee of public sector, and } 0 \text { if employee of private sector, self- } \\
\text { employed; } 1 \text { if employee of private sector, and } 0 \text { if employee of public sector, } \\
\text { self-employed; } 1 \text { if self-employed, and } 0 \text { if employee of public sector, employee } \\
\text { of private sector }\end{array}$ \\
\hline & Marital status & $\begin{array}{l}\text { Dummy }=1 \text { if married, and } 0 \text { if single, divorced/separated; } 1 \text { if single, and } 0 \text { if } \\
\text { married, divorced/separated; } 1 \text { if divorced/separated, and } 0 \text { if married, single }\end{array}$ \\
\hline & $\begin{array}{l}\text { Household } \\
\text { size }\end{array}$ & Number of people in a household \\
\hline & Age & Number of years, measured as an interval: $<25,26-35,36-45,46-55,>55$ \\
\hline \multirow{8}{*}{ Financial literacy } & \multirow[t]{4}{*}{ Budgeting } & Dummy $=1$ if borrower knows how to set up a personal budget, or 0 if otherwise \\
\hline & & Dummy $=1$ if borrower has a personal budget, and 0 if otherwise \\
\hline & & Dummy $=1$ if borrower has a household budget, 0 if otherwise \\
\hline & & $\begin{array}{l}\text { Dummy }=1 \text { if borrower is able to track your household expenditure, and } 0 \text { if } \\
\text { otherwise }\end{array}$ \\
\hline & \multirow[t]{4}{*}{ Savings } & $\begin{array}{l}\text { Dummy }=1 \text { if borrower knows how to calculate interest rates on accounts, and } 0 \\
\text { if otherwise }\end{array}$ \\
\hline & & Dummy $=1$ if borrower knows he should have save, and 0 if otherwise \\
\hline & & Dummy $=1$ if borrower saves, and 0 if otherwise \\
\hline & & $\begin{array}{l}\text { Dummy }=1 \text { if borrower is aware of some of the existing formal savings } \\
\text { mechanisms, and } 0 \text { if otherwise }\end{array}$ \\
\hline \multirow[t]{3}{*}{ Household budget } & $\begin{array}{l}\text { Housing } \\
\text { budget }\end{array}$ & Percentage of income spent on housing \\
\hline & Food budget & Percentage of income spent on food \\
\hline & $\begin{array}{l}\text { Clothing } \\
\text { budget }\end{array}$ & Percentage of income spent on clothing \\
\hline Household wealth & Income & $\begin{array}{l}\text { Monthly gross salary from employment in US dollars, measured as an interval: } \\
250-500,500-750,750-1,000,1,000-1,250,>1,250\end{array}$ \\
\hline
\end{tabular}




\begin{tabular}{|l|l|l|}
\hline \multirow{2}{*}{$\begin{array}{l}\text { Macroeconomic } \\
\text { Effects }\end{array}$} & Interest rates & $\begin{array}{l}\text { Five-point scale measure of a borrower's belief of the adverse effect of interest } \\
\text { rates movements on mortgage default. Scale: 1-strongly disagree, 2-disagree, 3- } \\
\text { indifferent, 4-agree, and 5-strongly agree. }\end{array}$ \\
\cline { 2 - 3 } & Inflation rate & $\begin{array}{l}\text { Five-point scale measure of a borrower's belief of the adverse effect of inflation } \\
\text { rates movements on mortgage default. Scale: 1-strongly disagree, 2-disagree, 3- } \\
\text { indifferent, 4-agree, and 5-strongly agree. }\end{array}$ \\
\cline { 2 - 3 } & Exchange rates & $\begin{array}{l}\text { Five-point scale measure of a borrower's belief of the adverse effect of exchange } \\
\text { rates movements on mortgage default. Scale: 1-strongly disagree, 2-disagree, 3- } \\
\text { indifferent, 4-agree, and 5-strongly agree. }\end{array}$ \\
\hline
\end{tabular}


Table 2 - Parameter Estimate and Statistics: Socio-demographic Characteristic.

\begin{tabular}{|c|c|c|c|c|c|c|c|}
\hline & $\sum_{\Sigma}^{\Xi}$ & 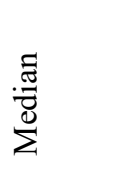 & $\frac{8}{8}$ & 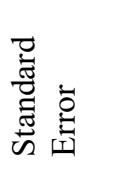 & : & 志 & 䓂 \\
\hline \multicolumn{8}{|l|}{ Demographics } \\
\hline Household Size & 1.330 & 1.000 & 1.000 & 0.055 & 1.000 & 3.000 & 100 \\
\hline Gender: Male & 0.568 & 1.000 & 1.000 & 0.055 & 0.000 & 1.000 & 81 \\
\hline Gender: Female & 0.444 & 0.000 & 0.000 & 0.056 & 0.000 & 1.000 & 81 \\
\hline Age & 2.679 & 2.000 & 2.000 & 0.096 & 1.000 & 5.000 & 81 \\
\hline Education Level: $1^{\text {st }}$ Degree & 0.556 & 1.000 & 1.000 & 0.056 & 0.000 & 1.000 & 81 \\
\hline Educational Level: $2^{\text {nd }}$ Degree & 0.222 & 0.000 & 0.000 & 0.046 & 0.000 & 1.000 & 81 \\
\hline Educational Level: HND & 0.222 & 0.000 & 0.000 & 0.046 & 0.000 & 1.000 & 81 \\
\hline Employer: Public Sector & 0.605 & 1.000 & 1.000 & 0.055 & 0.000 & 1.000 & 81 \\
\hline Employer: Private Sector & 0.259 & 0.000 & 0.000 & 0.049 & 0.000 & 1.000 & 81 \\
\hline Employer: Self Employed & 0.136 & 0.000 & 0.000 & 0.038 & 0.000 & 1.000 & 81 \\
\hline Marital Status: Married & 0.716 & 1.000 & 1.000 & 0.050 & 0.000 & 1.000 & 81 \\
\hline Marital Status: Single & 0.235 & 0.000 & 0.000 & 0.047 & 0.000 & 1.000 & 81 \\
\hline $\begin{array}{l}\text { Marital Status: Divorced } \\
\text { Financial Literacy }\end{array}$ & 0.025 & 0.000 & 0.000 & 0.017 & 0.000 & 1.000 & 81 \\
\hline Savings 1 & 0.280 & 0.000 & 0.000 & 0.053 & 0.000 & 2.000 & 100 \\
\hline Savings 2 & 0.630 & 1.000 & 0.000 & 0.065 & 0.000 & 2.000 & 100 \\
\hline Savings 3 & 0.440 & 0.000 & 0.000 & 0.064 & 0.000 & 2.000 & 100 \\
\hline Savings 4 & 0.490 & 0.000 & 0.000 & 0.063 & 0.000 & 2.000 & 100 \\
\hline Budgeting 1 & 0.310 & 0.000 & 0.000 & 0.054 & 0.000 & 2.000 & 100 \\
\hline Budgeting 2 & 0.400 & 0.000 & 0.000 & 0.057 & 0.000 & 2.000 & 100 \\
\hline Budgeting 3 & 0.520 & 0.000 & 0.000 & 0.064 & 0.000 & 2.000 & 100 \\
\hline Budgeting 4 & 0.620 & 0.000 & 0.000 & 0.071 & 0.000 & 2.000 & 100 \\
\hline Budgeting Proportion: Housing & 34.821 & 30.000 & 30.000 & 1.931 & 10.000 & 75.000 & 56 \\
\hline Budgeting Proportion: Food & 44.754 & 45.000 & 50.000 & 1.722 & 10.000 & 80.000 & 57 \\
\hline Budgeting Proportion: Clothing & 21.035 & 20.000 & 20.000 & 1.266 & 5.000 & 50.000 & 57 \\
\hline \multicolumn{8}{|l|}{ Risk Aversion } \\
\hline $\begin{array}{l}\text { Risk Tolerance Level } \\
\text { Income Level }\end{array}$ & 2.340 & 2.000 & 3.000 & 0.103 & 1.000 & 4.000 & 100 \\
\hline Monthly Salary & 2.920 & 3.000 & 2.000 & 0.110 & 2.000 & 6.000 & 100 \\
\hline $\begin{array}{l}\text { Perception about Economic } \\
\text { Factors }\end{array}$ & & & & & & & \\
\hline Interest Rate & 3.500 & 4.000 & 5.000 & 0.147 & 1.000 & 5.000 & 100 \\
\hline Inflation & 3.150 & 3.000 & 4.000 & 0.135 & 1.000 & 5.000 & 100 \\
\hline Exchange Rate & 3.340 & 4.000 & 4.000 & 0.122 & 1.000 & 5.000 & 100 \\
\hline National Growth Rate & 3.170 & 3.000 & 3.000 & 0.109 & 1.000 & 5.000 & 100 \\
\hline National Savings Habit & 3.300 & 3.000 & 3.000 & 0.111 & 1.000 & 5.000 & 100 \\
\hline
\end{tabular}




\begin{tabular}{|c|c|c|c|c|c|c|c|}
\hline Employment Rate & 3.540 & 4.000 & 5.000 & 0.140 & 1.000 & 5.000 & 100 \\
\hline \multicolumn{8}{|l|}{ Default Propensity } \\
\hline $\begin{array}{l}\text { Previous challenge repaying } \\
\text { any loan facility }\end{array}$ & 0.630 & 1.000 & 0.000 & 0.065 & 0.000 & 2.000 & 100 \\
\hline $\begin{array}{l}\text { Previous defaults on a loan } \\
\text { facility }\end{array}$ & 0.950 & 1.000 & 1.000 & 0.054 & 0.000 & 2.000 & 100 \\
\hline $\begin{array}{l}\text { Previous challenge repaying a } \\
\text { mortgage }\end{array}$ & 0.740 & 1.000 & 1.000 & 0.061 & 0.000 & 2.000 & 100 \\
\hline $\begin{array}{l}\text { Previously missed any monthly } \\
\text { payment of mortgage }\end{array}$ & 0.810 & 1.000 & 1.000 & 0.060 & 0.000 & 2.000 & 100 \\
\hline $\begin{array}{l}\text { Ability to fully complete } \\
\text { payment of mortgage } \\
\text { Mortgage Access Constraints }\end{array}$ & 0.340 & 0.000 & 0.000 & 0.059 & 0.000 & 2.000 & 100 \\
\hline Interest rate & 0.300 & 0.000 & 0.000 & 0.052 & 0.000 & 2.000 & 100 \\
\hline Collateral security & 0.270 & 0.000 & 0.000 & 0.049 & 0.000 & 2.000 & 100 \\
\hline Loan size & 0.330 & 0.000 & 0.000 & 0.055 & 0.000 & 2.000 & 100 \\
\hline
\end{tabular}


Table 3 - Respondents Demographic Profile

\begin{tabular}{|c|c|c|}
\hline $\begin{array}{c}\text { Description } \\
\text { Age }\end{array}$ & Age & Proportion (\%) \\
\hline$<25$ & 3 & 3 \\
\hline $26-35$ & 51 & 51 \\
\hline $36-45$ & 30 & 30 \\
\hline $46-55$ & 13 & 13 \\
\hline$>55$ & 3 & 3 \\
\hline \multicolumn{3}{|l|}{ Gender } \\
\hline Male & 55 & 55 \\
\hline Female & 45 & 45 \\
\hline \multicolumn{3}{|l|}{ Marital Status } \\
\hline Divorced/Separated & 5 & 5 \\
\hline Marital & 66 & 66 \\
\hline Single & 29 & 29 \\
\hline \multicolumn{3}{|l|}{ Educational Level } \\
\hline Below HND & 3 & 3 \\
\hline Technician/HND & 21 & 21 \\
\hline Bachelor & 55 & 55 \\
\hline Master & 20 & 20 \\
\hline Doctorate & 1 & 1 \\
\hline \multicolumn{3}{|l|}{ Income Levels (US\$ per } \\
\hline month) & 46 & 46 \\
\hline $250-500$ & 30 & 30 \\
\hline $500-750$ & 14 & 14 \\
\hline $750-1,000$ & 6 & 6 \\
\hline $1,000-1,250$ & 4 & 4 \\
\hline$>1,250$ & & \\
\hline
\end{tabular}


Table 4 - Baseline Logistics Regression

Table 4 presents baseline logistic regression estimations of mortgage default propensity measured by four different but related variables. Models one (M1) and two (M2) predict borrowers' previous challenges repaying any loan and actual default on the repayment of any loan respectively. Models three (M3) and four (M4) specially measure borrowers' previous challenges repaying a mortgage and their actual default on mortgage repayment accordingly. Only demographic variables are included as independent variables in the baseline regressions. They are household size, age, gender dummy, education dummies, employment dummies and marital status dummy. ${ }^{*}, * * * *$ represent statistical significance at the $10 \%, 5 \%$, and $1 \%$ levels, respectively.

\begin{tabular}{|c|c|c|c|c|}
\hline & M1 & M2 & M3 & M4 \\
\hline \multirow[t]{2}{*}{ Household Size } & $\begin{array}{c}-0.581 \\
\end{array}$ & -0.313 & $-0.854 *$ & $-1.306^{* *}$ \\
\hline & -0.443 & -0.583 & -0.469 & -0.522 \\
\hline \multirow[t]{2}{*}{ Female: Dummy } & $1.050^{* *}$ & $1.432 * *$ & 0.212 & 0.855 \\
\hline & -0.497 & -0.641 & -0.502 & -0.562 \\
\hline \multirow[t]{2}{*}{ Age } & $0.780^{* *}$ & -0.026 & $0.605^{*}$ & 0.65 \\
\hline & -0.339 & -0.376 & -0.364 & -0.397 \\
\hline \multirow[t]{2}{*}{ First Degree: Dummy } & -0.468 & -0.651 & 0.149 & 0.062 \\
\hline & -0.651 & -0.863 & -0.669 & -0.708 \\
\hline \multirow[t]{2}{*}{ Higher National Diploma: Dummy } & 0.056 & -0.631 & -0.062 & -0.472 \\
\hline & -0.752 & -0.931 & -0.769 & -0.799 \\
\hline \multirow[t]{2}{*}{ Self Employed } & $-1.113 * * *$ & $-1.478^{*}$ & $-2.316 * * *$ & $-2.048 * *$ \\
\hline & -0.586 & -0.798 & -0.803 & -0.811 \\
\hline \multirow[t]{2}{*}{ Private Sector Employee } & $-2.075 * * *$ & -0.992 & $-1.330^{* *}$ & $-1.578^{* *}$ \\
\hline & -0.785 & -0.686 & -0.595 & -0.658 \\
\hline \multirow[t]{2}{*}{ Marital Status: Single } & $2.161 * * *$ & 0.455 & $2.113^{* * *}$ & $2.816^{* * *}$ \\
\hline & -0.654 & -0.741 & -0.716 & -0.905 \\
\hline \multirow[t]{2}{*}{ Constant } & -1.487 & 2.355 & 0.162 & 0.818 \\
\hline & -1.327 & -1.688 & -1.365 & -1.445 \\
\hline
\end{tabular}


Table 5 - Financial Literacy, Risk Tolerance and Previous Challenges Repaying Other Loans

\begin{tabular}{|c|c|c|c|c|c|c|c|c|c|c|c|c|}
\hline & M1 & M2 & M3 & M4 & M5 & M6 & M7 & M8 & M9 & M10 & M11 & M12 \\
\hline Household Size & $\begin{array}{l}-0.631 \\
(0.467)\end{array}$ & $\begin{array}{l}-0.578 \\
(0.446)\end{array}$ & $\begin{array}{l}-0.478 \\
(0.457)\end{array}$ & $\begin{array}{l}-0.489 \\
(0.448)\end{array}$ & $\begin{array}{l}-0.428 \\
(0.453)\end{array}$ & $\begin{array}{l}-0.603 \\
(0.456)\end{array}$ & $\begin{array}{l}-0.700 \\
(0.476)\end{array}$ & $\begin{array}{l}-0.527 \\
(0.460)\end{array}$ & $\begin{array}{l}-0.596 \\
(0.448)\end{array}$ & $\begin{array}{l}-0.558 \\
(0.448)\end{array}$ & $\begin{array}{l}-0.685 \\
(0.462)\end{array}$ & $\begin{array}{l}-0.545 \\
(0.451)\end{array}$ \\
\hline Female: Dummy & $\begin{array}{l}0.715 \\
(0.531)\end{array}$ & $\begin{array}{l}0.978^{* *} \\
(0.504)\end{array}$ & $\begin{array}{l}0.792 \\
(0.520)\end{array}$ & $\begin{array}{l}0.876^{*} \\
(0.512)\end{array}$ & $\begin{array}{l}0.821 \\
(0.516)\end{array}$ & $\begin{array}{l}0.951^{*} \\
(0.512)\end{array}$ & $\begin{array}{l}0.886^{*} \\
(0.518)\end{array}$ & $\begin{array}{l}0.770 \\
(0.517)\end{array}$ & $\begin{array}{l}1.046^{* *} \\
(0.503)\end{array}$ & $\begin{array}{l}1.075^{* *} \\
(0.498)\end{array}$ & $\begin{array}{l}1.090 * * \\
(0.512)\end{array}$ & $\begin{array}{l}1.062 * * \\
(0.499)\end{array}$ \\
\hline Age & $\begin{array}{l}0.809^{* *} \\
(0.344)\end{array}$ & $\begin{array}{l}0.754 * * \\
(0.339)\end{array}$ & $\begin{array}{l}0.725^{* *} \\
(0.341)\end{array}$ & $\begin{array}{l}0.768^{* *} \\
(0.340)\end{array}$ & $\begin{array}{l}0.821 * * \\
(0.339)\end{array}$ & $\begin{array}{l}0.765^{* *} \\
(0.344)\end{array}$ & $\begin{array}{l}0.748 * * \\
(0.340)\end{array}$ & $\begin{array}{l}0.734^{* *} \\
(0.337)\end{array}$ & $\begin{array}{l}0.788^{* *} \\
(0.341)\end{array}$ & $\begin{array}{l}0.777 * * \\
(0.339)\end{array}$ & $\begin{array}{l}0.780^{* *} \\
(0.342)\end{array}$ & $\begin{array}{l}0.771 * * \\
(0.340)\end{array}$ \\
\hline First Degree: Dummy & $\begin{array}{l}-0.690 \\
(0.671)\end{array}$ & $\begin{array}{l}-0.537 \\
(0.660)\end{array}$ & $\begin{array}{l}-0.682 \\
(0.676)\end{array}$ & $\begin{array}{l}-0.530 \\
(0.658)\end{array}$ & $\begin{array}{l}-0.475 \\
(0.659)\end{array}$ & $\begin{array}{l}-0.680 \\
(0.676)\end{array}$ & $\begin{array}{l}-0.774 \\
(0.685)\end{array}$ & $\begin{array}{l}-0.627 \\
(0.670)\end{array}$ & $\begin{array}{l}-0.442 \\
(0.653)\end{array}$ & $\begin{array}{l}-0.525 \\
(0.660)\end{array}$ & $\begin{array}{l}-0.738 \\
(0.691)\end{array}$ & $\begin{array}{l}-0.445 \\
(0.656)\end{array}$ \\
\hline $\begin{array}{l}\text { Higher National Diploma: } \\
\text { Dummy }\end{array}$ & $\begin{array}{l}-0.606 \\
(0.826)\end{array}$ & $\begin{array}{l}-0.072 \\
(0.765)\end{array}$ & $\begin{array}{l}-0.304 \\
(0.801)\end{array}$ & $\begin{array}{l}-0.154 \\
(0.771)\end{array}$ & $\begin{array}{l}-0.140 \\
(0.785)\end{array}$ & $\begin{array}{l}-0.217 \\
(0.782)\end{array}$ & $\begin{array}{l}-0.599 \\
(0.820)\end{array}$ & $\begin{array}{l}-0.189 \\
(0.785)\end{array}$ & $\begin{array}{l}0.043 \\
(0.757)\end{array}$ & $\begin{array}{l}0.016 \\
(0.761)\end{array}$ & $\begin{array}{l}-0.218 \\
(0.784)\end{array}$ & $\begin{array}{l}0.081 \\
(0.757)\end{array}$ \\
\hline Self Employed & $\begin{array}{l}-2.085^{* *} \\
(0.867)\end{array}$ & $\begin{array}{l}-2.120 * * * \\
(0.787)\end{array}$ & $\begin{array}{l}-2.180 * * * \\
(0.824)\end{array}$ & $\begin{array}{l}-2.139 * * * \\
(0.802)\end{array}$ & $\begin{array}{l}-2.139 * * * \\
(0.816)\end{array}$ & $\begin{array}{l}-2.169 * * * \\
(0.818)\end{array}$ & $\begin{array}{l}-2.068 * * \\
(0.828)\end{array}$ & $\begin{array}{l}-1.999 * * \\
(0.794)\end{array}$ & $\begin{array}{l}-2.067 * * * \\
(0.787)\end{array}$ & $\begin{array}{l}-2.104 * * * \\
(0.794)\end{array}$ & $\begin{array}{l}-2.132 * * \\
(0.828)\end{array}$ & $\begin{array}{l}-2.090 * * * \\
(0.787)\end{array}$ \\
\hline Private Sector Employee & $\begin{array}{l}-1.291 * * \\
(0.631)\end{array}$ & $\begin{array}{l}-1.176^{* *} \\
(0.599)\end{array}$ & $\begin{array}{l}-1.181^{* *} \\
(0.614)\end{array}$ & $\begin{array}{l}-1.029^{*} \\
(0.593)\end{array}$ & $\begin{array}{l}-1.065^{*} \\
(0.597)\end{array}$ & $\begin{array}{l}-1.153^{* *} \\
(0.607)\end{array}$ & $\begin{array}{l}-1.217 * * \\
(0.615)\end{array}$ & $\begin{array}{l}-1.248^{* *} \\
(0.621)\end{array}$ & $\begin{array}{l}-1.044^{*} \\
(0.593)\end{array}$ & $\begin{array}{l}-1.131^{* *} \\
(0.586)\end{array}$ & $\begin{array}{l}-0.957 \\
(0.595)\end{array}$ & $\begin{array}{l}-1.107^{*} \\
(0.586)\end{array}$ \\
\hline Marital Status: Single & $\begin{array}{l}2.249 * * * \\
(0.725)\end{array}$ & $\begin{array}{l}1.998 * * * \\
(0.676)\end{array}$ & $\begin{array}{l}2.009 * * * \\
(0.695)\end{array}$ & $\begin{array}{l}2.028 * * * \\
(0.672)\end{array}$ & $\begin{array}{l}2.043 * * * \\
(0.679)\end{array}$ & $\begin{array}{l}1.989 * * * \\
(0.674)\end{array}$ & $\begin{array}{l}1.916 * * * \\
(0.697)\end{array}$ & $\begin{array}{l}1.937 * * * \\
(0.674)\end{array}$ & $\begin{array}{l}2.196 * * * \\
(0.662)\end{array}$ & $\begin{array}{l}2.165 * * * \\
(0.652)\end{array}$ & $\begin{array}{l}2.293 * * * \\
(0.671)\end{array}$ & $\begin{array}{l}2.138 \\
(0.655)\end{array}$ \\
\hline $\begin{array}{l}\text { Knowledge of Need for } \\
\text { Emergency Funds: Dummy }\end{array}$ & $\begin{array}{l}2.126^{* * * *} \\
(0.780)\end{array}$ & & & & & & & & & & & \\
\hline $\begin{array}{l}\text { Ownership of Emergency } \\
\text { Fund: Dummy }\end{array}$ & & $\begin{array}{l}0.417 \\
(0.435)\end{array}$ & & & & & & & & & & \\
\hline $\begin{array}{l}\text { Knowledge of where to } \\
\text { keep emergency fund }\end{array}$ & & & $\begin{array}{l}1.177 * * \\
(0.515)\end{array}$ & & & & & & & & & \\
\hline $\begin{array}{l}\text { Knowledge of how to } \\
\text { calculate interest rates }\end{array}$ & & & & $\begin{array}{l}0.716 \\
(0.471)\end{array}$ & & & & & & & & \\
\hline $\begin{array}{l}\text { Knowledge of how to set up } \\
\text { personal budgets }\end{array}$ & & & & & $\begin{array}{l}1.200^{* *} \\
(0.607)\end{array}$ & & & & & & & \\
\hline $\begin{array}{l}\text { Ownership of a personal } \\
\text { budget }\end{array}$ & & & & & & $\begin{array}{l}1.036^{* *} \\
(0.509)\end{array}$ & & & & & & \\
\hline $\begin{array}{l}\text { Ownership of a household } \\
\text { budget }\end{array}$ & & & & & & & $\begin{array}{l}1.303 * * \\
(0.503)\end{array}$ & & & & & \\
\hline $\begin{array}{l}\text { Ability to track household } \\
\text { expenditure }\end{array}$ & & & & & & & & $\begin{array}{l}1.006^{* *} \\
(0.417)\end{array}$ & & & & \\
\hline $\begin{array}{l}\text { Percentage of housing } \\
\text { budget }\end{array}$ & & & & & & & & & $\begin{array}{l}-0.022 \\
(0.023)\end{array}$ & & & \\
\hline Percentage of food budget & & & & & & & & & & $\begin{array}{l}-0.019 \\
(0.025)\end{array}$ & & \\
\hline $\begin{array}{l}\text { Percentage of clothing } \\
\text { budget }\end{array}$ & & & & & & & & & & & $\begin{array}{l}0.073^{* *} \\
(0.039)\end{array}$ & \\
\hline Description & & & & & & & & & & & & $\begin{array}{l}-0.099 \\
(0.239)\end{array}$ \\
\hline
\end{tabular}




\begin{tabular}{|c|c|c|c|c|c|c|c|c|c|c|c|c|}
\hline Constant & $\begin{array}{l}-1.428 \\
(1.384) \\
\end{array}$ & $\begin{array}{l}-1.497 \\
(1.335) \\
\end{array}$ & $\begin{array}{l}-1.483 \\
(1.374) \\
\end{array}$ & $\begin{array}{l}-1.699 \\
(1.356)\end{array}$ & $\begin{array}{l}-1.893 \\
(1.368) \\
\end{array}$ & $\begin{array}{l}-1.489 \\
(1.366) \\
\end{array}$ & $\begin{array}{l}-1.330 \\
(1.375) \\
\end{array}$ & $\begin{array}{l}-1.638 \\
(1.371) \\
\end{array}$ & $\begin{array}{l}-0.763 \\
(1.527) \\
\end{array}$ & $\begin{array}{l}-0.641 \\
(1.744) \\
\end{array}$ & $\begin{array}{l}-2.764^{*} \\
(1.538) \\
\end{array}$ & $\begin{array}{l}-1.305 \\
(1.400) \\
\end{array}$ \\
\hline
\end{tabular}


Table 6 - Financial Literacy, Risk Tolerance and Defaults on Other Loans

\begin{tabular}{|c|c|c|c|c|c|c|c|c|c|c|c|c|}
\hline & M1 & M2 & M3 & M4 & M5 & M6 & M7 & M8 & M9 & M10 & M11 & M12 \\
\hline Household Size & $\begin{array}{l}-0.311 \\
(0.577)\end{array}$ & $\begin{array}{l}-0.311 \\
(0.584)\end{array}$ & $\begin{array}{l}-0.290 \\
(0.587)\end{array}$ & $\begin{array}{l}-0.291 \\
(0.582)\end{array}$ & $\begin{array}{l}-0.282 \\
(0.590)\end{array}$ & $\begin{array}{l}-0.307 \\
(0.582)\end{array}$ & $\begin{array}{l}-0.306 \\
(0.585)\end{array}$ & $\begin{array}{l}-0.252 \\
(0.588)\end{array}$ & $\begin{array}{l}-0.324 \\
(0.587)\end{array}$ & $\begin{array}{l}-0.277 \\
(0.573)\end{array}$ & $\begin{array}{l}-0.407 \\
(0.589)\end{array}$ & $\begin{array}{l}-0.347 \\
(0.589)\end{array}$ \\
\hline Female: Dummy & $\begin{array}{l}1.326^{* * *} \\
(0.659)\end{array}$ & $\begin{array}{l}1.467 * * \\
(0.655)\end{array}$ & $\begin{array}{l}1.389 * * \\
(0.663)\end{array}$ & $\begin{array}{l}1.388^{* *} \\
(0.654)\end{array}$ & $\begin{array}{l}1.385^{* *} \\
(0.660)\end{array}$ & $\begin{array}{l}1.362^{* *} \\
(0.649)\end{array}$ & $\begin{array}{l}1.484 * * \\
(0.654)\end{array}$ & $\begin{array}{l}1.257^{* *} \\
(0.654)\end{array}$ & $\begin{array}{l}1.432 * * \\
(0.647)\end{array}$ & $\begin{array}{l}1.489^{* *} \\
(0.644)\end{array}$ & $\begin{array}{l}1.467^{* *} \\
(0.660)\end{array}$ & $\begin{array}{l}1.412 * * \\
(0.642)\end{array}$ \\
\hline Age & $\begin{array}{l}-0.039 \\
(0.373)\end{array}$ & $\begin{array}{l}-0.011 \\
(0.381)\end{array}$ & $\begin{array}{l}-0.043 \\
(0.380)\end{array}$ & $\begin{array}{l}-0.046 \\
(0.378)\end{array}$ & $\begin{array}{l}-0.024 \\
(0.374)\end{array}$ & $\begin{array}{l}-0.076 \\
(0.382)\end{array}$ & $\begin{array}{l}-0.009 \\
(0.381)\end{array}$ & $\begin{array}{l}-0.092 \\
(0.374)\end{array}$ & $\begin{array}{l}-0.058 \\
(0.376)\end{array}$ & $\begin{array}{l}-0.048 \\
(0.378)\end{array}$ & $\begin{array}{l}-0.090 \\
(0.384)\end{array}$ & $\begin{array}{l}-0.008 \\
(0.379)\end{array}$ \\
\hline First Degree: Dummy & $\begin{array}{l}-0.698 \\
(0.863)\end{array}$ & $\begin{array}{l}-0.626 \\
(0.868)\end{array}$ & $\begin{array}{l}-0.679 \\
(0.870)\end{array}$ & $\begin{array}{l}-0.680 \\
(0.868)\end{array}$ & $\begin{array}{l}-0.650 \\
(0.861)\end{array}$ & $\begin{array}{l}-0.779 \\
(0.881)\end{array}$ & $\begin{array}{l}-0.613 \\
(0.872)\end{array}$ & $\begin{array}{l}-0.723 \\
(0.866)\end{array}$ & $\begin{array}{l}-0.669 \\
(0.870)\end{array}$ & $\begin{array}{l}-0.716 \\
(0.863)\end{array}$ & $\begin{array}{l}-1.036 \\
(0.914)\end{array}$ & $\begin{array}{l}-0.686 \\
(0.868)\end{array}$ \\
\hline Higher National Diploma: Dummy & $\begin{array}{l}-0.754 \\
(0.954)\end{array}$ & $\begin{array}{l}-0.585 \\
(0.946)\end{array}$ & $\begin{array}{l}-0.665 \\
(0.942)\end{array}$ & $\begin{array}{l}-0.699 \\
(0.953)\end{array}$ & $\begin{array}{l}-0.645 \\
(0.933)\end{array}$ & $\begin{array}{l}-0.750 \\
(0.950)\end{array}$ & $\begin{array}{l}-0.537 \\
(0.956)\end{array}$ & $\begin{array}{l}-0.672 \\
(0.944)\end{array}$ & $\begin{array}{l}-0.657 \\
(0.937)\end{array}$ & $\begin{array}{l}-0.675 \\
(0.931)\end{array}$ & $\begin{array}{l}-0.928 \\
(0.961)\end{array}$ & $\begin{array}{l}-0.657 \\
(0.933)\end{array}$ \\
\hline Self Employed & $\begin{array}{l}-1.400^{*} \\
(0.814)\end{array}$ & $\begin{array}{l}-1.473^{*} \\
(0.796)\end{array}$ & $\begin{array}{l}-1.470^{*} \\
(0.801)\end{array}$ & $\begin{array}{l}-1.484^{*} \\
(0.803)\end{array}$ & $\begin{array}{l}-1.465^{*} \\
(0.803)\end{array}$ & $\begin{array}{l}-1.478^{*} \\
(0.812)\end{array}$ & $\begin{array}{l}-1.528^{*} \\
(0.805)\end{array}$ & $\begin{array}{l}-1.420^{*} \\
(0.814)\end{array}$ & $\begin{array}{l}-1.492 * \\
(0.798)\end{array}$ & $\begin{array}{l}-1.497^{*} \\
(0.809)\end{array}$ & $\begin{array}{l}-1.566^{*} \\
(0.832)\end{array}$ & $\begin{array}{l}-1.447^{*} \\
(0.800)\end{array}$ \\
\hline Private Sector Employee & $\begin{array}{l}-1.006 \\
(0.685)\end{array}$ & $\begin{array}{l}-0.982 \\
(0.689)\end{array}$ & $\begin{array}{l}-0.991 \\
(0.684)\end{array}$ & $\begin{array}{l}-0.976 \\
(0.685)\end{array}$ & $\begin{array}{l}-0.982 \\
(0.685)\end{array}$ & $\begin{array}{l}-0.991 \\
(0.684)\end{array}$ & $\begin{array}{l}-0.989 \\
(0.690)\end{array}$ & $\begin{array}{l}-1.035 \\
(0.683)\end{array}$ & $\begin{array}{l}-0.942 \\
(0.691)\end{array}$ & $\begin{array}{l}-1.050 \\
(0.703)\end{array}$ & $\begin{array}{l}-0.813 \\
(0.696)\end{array}$ & $\begin{array}{l}-0.978 \\
(0.690)\end{array}$ \\
\hline Marital Status: Single & $\begin{array}{l}0.425 \\
(0.750)\end{array}$ & $\begin{array}{l}0.514 \\
(0.774)\end{array}$ & $\begin{array}{l}0.417 \\
(0.757)\end{array}$ & $\begin{array}{l}0.385 \\
(0.767)\end{array}$ & $\begin{array}{l}0.416 \\
(0.754)\end{array}$ & $\begin{array}{l}0.287 \\
(0.762)\end{array}$ & $\begin{array}{l}0.546 \\
(0.772)\end{array}$ & $\begin{array}{l}0.245 \\
(0.765)\end{array}$ & $\begin{array}{l}0.502 \\
(0.753)\end{array}$ & $\begin{array}{l}0.383 \\
(0.743)\end{array}$ & $\begin{array}{l}0.579 \\
(0.767)\end{array}$ & $\begin{array}{l}0.504 \\
(0.752)\end{array}$ \\
\hline $\begin{array}{l}\text { Knowledge of Need for Emergency Funds: } \\
\text { Dummy }\end{array}$ & $\begin{array}{l}0.536 \\
(0.835)\end{array}$ & & & & & & & & & & & \\
\hline Ownership of Emergency Fund: Dummy & & $\begin{array}{l}-0.145 \\
(0.545)\end{array}$ & & & & & & & & & & \\
\hline Knowledge of where to keep emergency fund & & & $\begin{array}{l}0.147 \\
(0.590)\end{array}$ & & & & & & & & & \\
\hline Knowledge of how to calculate interest rates & & & & $\begin{array}{l}0.203 \\
(0.596)\end{array}$ & & & & & & & & \\
\hline Knowledge of how to set up personal budgets & & & & & $\begin{array}{l}0.195 \\
(0.720)\end{array}$ & & & & & & & \\
\hline Ownership of a personal budget & & & & & & $\begin{array}{l}0.587 \\
(0.661)\end{array}$ & & & & & & \\
\hline Ownership of a household budget & & & & & & & $\begin{array}{l}-0.233 \\
(0.546)\end{array}$ & & & & & \\
\hline Ability to track household expenditure & & & & & & & & $\begin{array}{l}0.613 \\
(0.547)\end{array}$ & & & & \\
\hline Percentage of housing budget & & & & & & & & & $\begin{array}{l}-0.012 \\
(0.028)\end{array}$ & & & \\
\hline Percentage of food budget & & & & & & & & & & $\begin{array}{l}-0.028 \\
(0.033)\end{array}$ & & \\
\hline Percentage of clothing budget & & & & & & & & & & & $\begin{array}{l}0.090^{*} \\
(0.052)\end{array}$ & \\
\hline Description & & & & & & & & & & & & $\begin{array}{l}0.126 \\
(0.289)\end{array}$ \\
\hline
\end{tabular}


Table 7- Financial Literacy, Risk Tolerance and Previous Challenges Repaying Mortgages

\begin{tabular}{|c|c|c|c|c|c|c|c|c|c|c|c|c|}
\hline & M1 & M2 & M3 & M4 & M5 & M6 & M7 & M8 & M9 & M10 & M11 & M12 \\
\hline Household Size & $\begin{array}{l}-0.980 * * \\
(0.508)\end{array}$ & $\begin{array}{l}-0.870^{*} \\
(0.496)\end{array}$ & $\begin{array}{l}-0.763 \\
(0.491)\end{array}$ & $\begin{array}{l}-0.728 \\
(0.472)\end{array}$ & $\begin{array}{l}-0.689 \\
(0.482)\end{array}$ & $\begin{array}{l}-0.904 * \\
(0.504)\end{array}$ & $\begin{array}{l}-0.918^{*} \\
(0.495)\end{array}$ & $\begin{array}{l}-0.822 \\
(0.527)\end{array}$ & $\begin{array}{l}-0.923^{*} \\
(0.487)\end{array}$ & $\begin{array}{l}-0.902 * \\
(0.477)\end{array}$ & $\begin{array}{l}-0.918 * \\
(0.477)\end{array}$ & $\begin{array}{l}-0.967 * * \\
(0.492)\end{array}$ \\
\hline Female: Dummy & $\begin{array}{l}-0.298 \\
(0.566)\end{array}$ & $\begin{array}{l}0.015 \\
(0.535)\end{array}$ & $\begin{array}{l}-0.175 \\
(0.544)\end{array}$ & $\begin{array}{l}-0.049 \\
(0.529)\end{array}$ & $\begin{array}{l}-0.191 \\
(0.543)\end{array}$ & $\begin{array}{l}-0.036 \\
(0.539)\end{array}$ & $\begin{array}{l}0.050 \\
(0.522)\end{array}$ & $\begin{array}{l}-0.346 \\
(0.565)\end{array}$ & $\begin{array}{l}0.195 \\
(0.525)\end{array}$ & $\begin{array}{l}0.212 \\
(0.507)\end{array}$ & $\begin{array}{l}0.189 \\
(0.509)\end{array}$ & $\begin{array}{l}0.190 \\
(0.504)\end{array}$ \\
\hline Age & $\begin{array}{l}0.595 \\
(0.367)\end{array}$ & $\begin{array}{l}0.532 \\
(0.361)\end{array}$ & $\begin{array}{l}0.478 \\
(0.360)\end{array}$ & $\begin{array}{l}0.574 \\
(0.360)\end{array}$ & $\begin{array}{l}0.625^{*} \\
(0.357)\end{array}$ & $\begin{array}{l}0.554 \\
(0.368)\end{array}$ & $\begin{array}{l}0.542 \\
(0.357)\end{array}$ & $\begin{array}{l}0.519 \\
(0.367)\end{array}$ & $\begin{array}{l}0.610 \\
(0.373)\end{array}$ & $\begin{array}{l}0.616^{*} \\
(0.367)\end{array}$ & $\begin{array}{l}0.578 \\
(0.364)\end{array}$ & $\begin{array}{l}0.652 * \\
(0.371)\end{array}$ \\
\hline First Degree: Dummy & $\begin{array}{l}-0.059 \\
(0.704)\end{array}$ & $\begin{array}{l}-0.048 \\
(0.705)\end{array}$ & $\begin{array}{l}-0.183 \\
(0.708)\end{array}$ & $\begin{array}{l}0.099 \\
(0.680)\end{array}$ & $\begin{array}{l}0.152 \\
(0.683)\end{array}$ & $\begin{array}{l}-0.132 \\
(0.709)\end{array}$ & $\begin{array}{l}-0.095 \\
(0.690)\end{array}$ & $\begin{array}{l}-0.033 \\
(0.725)\end{array}$ & $\begin{array}{l}0.256 \\
(0.695)\end{array}$ & $\begin{array}{l}0.223 \\
(0.680)\end{array}$ & $\begin{array}{l}0.012 \\
(0.688)\end{array}$ & $\begin{array}{l}0.096 \\
(0.671)\end{array}$ \\
\hline $\begin{array}{l}\text { Higher National Diploma: } \\
\text { Dummy }\end{array}$ & $\begin{array}{l}-1.089 \\
(0.910)\end{array}$ & $\begin{array}{l}-0.524 \\
(0.814)\end{array}$ & $\begin{array}{l}-0.725 \\
(0.873)\end{array}$ & $\begin{array}{l}-0.422 \\
(0.809)\end{array}$ & $\begin{array}{l}-0.445 \\
(0.844)\end{array}$ & $\begin{array}{l}-0.587 \\
(0.842)\end{array}$ & $\begin{array}{l}-0.663 \\
(0.840)\end{array}$ & $\begin{array}{l}-0.557 \\
(0.869)\end{array}$ & $\begin{array}{l}-0.064 \\
(0.783)\end{array}$ & $\begin{array}{l}-0.017 \\
(0.773)\end{array}$ & $\begin{array}{l}-0.214 \\
(0.788)\end{array}$ & $\begin{array}{l}-0.128 \\
(0.772)\end{array}$ \\
\hline Self Employed & $\begin{array}{l}-2.829 * * * \\
(1.024)\end{array}$ & $\begin{array}{l}-2.580^{* * * *} \\
(0.838)\end{array}$ & $\begin{array}{l}-2.701 * * * \\
(0.921)\end{array}$ & $\begin{array}{l}-2.516^{* * *} \\
(0.854)\end{array}$ & $\begin{array}{l}-2.734 * * * \\
(0.924)\end{array}$ & $\begin{array}{l}-2.660 * * * \\
(0.900)\end{array}$ & $\begin{array}{l}-2.267 * * * \\
(0.830)\end{array}$ & $\begin{array}{l}-2.496^{* * * *} \\
(0.866)\end{array}$ & $\begin{array}{l}-2.400 * * * \\
(0.837)\end{array}$ & $\begin{array}{l}-2.342 * * * \\
(0.806)\end{array}$ & $\begin{array}{l}-2.294 * * * \\
(0.828)\end{array}$ & $\begin{array}{l}-2.347 * * * \\
(0.804)\end{array}$ \\
\hline Private Sector Employee & $\begin{array}{l}-1.623^{* *} \\
(0.668)\end{array}$ & $\begin{array}{l}-1.585^{* *} \\
(0.649)\end{array}$ & $\begin{array}{l}-1.478^{* *} \\
(0.640)\end{array}$ & $\begin{array}{l}-1.218^{* *} \\
(0.604)\end{array}$ & $\begin{array}{l}-1.284 * * \\
(0.614)\end{array}$ & $\begin{array}{l}-1.427 * * \\
(0.634)\end{array}$ & $\begin{array}{l}-1.403 * * \\
(0.615)\end{array}$ & $\begin{array}{l}-1.736^{* *} \\
(0.695)\end{array}$ & $\begin{array}{l}-1.206^{* *} \\
(0.602)\end{array}$ & $\begin{array}{l}-1.330^{* *} \\
(0.599)\end{array}$ & $\begin{array}{l}-1.203 * * \\
(0.597)\end{array}$ & $\begin{array}{l}-1.373 * * \\
(0.605)\end{array}$ \\
\hline Marital Status: Single & $\begin{array}{l}2.360 * * * \\
(0.857)\end{array}$ & $\begin{array}{l}1.645^{* *} \\
(0.757)\end{array}$ & $\begin{array}{l}1.963 * * \\
(0.783)\end{array}$ & $\begin{array}{l}1.863 * * \\
(0.735)\end{array}$ & $\begin{array}{l}2.063 * * * \\
(0.779)\end{array}$ & $\begin{array}{l}1.888 * * \\
(0.764)\end{array}$ & $\begin{array}{l}1.807 * * \\
(0.747)\end{array}$ & $\begin{array}{l}1.749 * * \\
(0.755)\end{array}$ & $\begin{array}{l}2.248 * * * \\
(0.742)\end{array}$ & $\begin{array}{l}2.151^{* * * *} \\
(0.723)\end{array}$ & $\begin{array}{l}2.165 * * * \\
(0.723)\end{array}$ & $\begin{array}{l}2.263 * * * \\
(0.751)\end{array}$ \\
\hline $\begin{array}{l}\text { Knowledge of Need for } \\
\text { Emergency Funds: Dummy }\end{array}$ & $\begin{array}{l}3.601 * * * \\
(1.227)\end{array}$ & & & & & & & & & & & \\
\hline $\begin{array}{l}\text { Ownership of Emergency } \\
\text { Fund: Dummy }\end{array}$ & & $\begin{array}{l}1.303 * * \\
(0.530)\end{array}$ & & & & & & & & & & \\
\hline $\begin{array}{l}\text { Knowledge of where to } \\
\text { keep emergency fund }\end{array}$ & & & $\begin{array}{l}0.492 * * * \\
(1.454)\end{array}$ & & & & & & & & & \\
\hline $\begin{array}{l}\text { Knowledge of how to } \\
\text { calculate interest rates }\end{array}$ & & & & $\begin{array}{l}1.139 * * \\
(0.563)\end{array}$ & & & & & & & & \\
\hline $\begin{array}{l}\text { Knowledge of how to set up } \\
\text { personal budgets }\end{array}$ & & & & & $\begin{array}{l}2.113^{* *} \\
(0.862)\end{array}$ & & & & & & & \\
\hline $\begin{array}{l}\text { Ownership of a personal } \\
\text { budget }\end{array}$ & & & & & & $\begin{array}{l}1.809^{* * *} \\
(0.663)\end{array}$ & & & & & & \\
\hline $\begin{array}{l}\text { Ownership of a household } \\
\text { budget }\end{array}$ & & & & & & & $\begin{array}{l}1.157 * * \\
(0.524)\end{array}$ & & & & & \\
\hline $\begin{array}{l}\text { Ability to track household } \\
\text { expenditure }\end{array}$ & & & & & & & & $\begin{array}{l}1.893 * * * \\
(0.559)\end{array}$ & & & & \\
\hline $\begin{array}{l}\begin{array}{l}\text { Percentage of housing } \\
\text { budget }\end{array} \\
\end{array}$ & & & & & & & & & $\begin{array}{l}-0.049 * * \\
(0.025)\end{array}$ & & & \\
\hline Percentage of food budget & & & & & & & & & & $\begin{array}{l}0.023 \\
(0.026)\end{array}$ & & \\
\hline $\begin{array}{l}\text { Percentage of clothing } \\
\text { budget }\end{array}$ & & & & & & & & & & & $\begin{array}{l}0.048 \\
(0.040)\end{array}$ & \\
\hline Description & & & & & & & & & & & & $\begin{array}{l}0.236 \\
(0.260)\end{array}$ \\
\hline
\end{tabular}




\begin{tabular}{|c|c|c|c|c|c|c|c|c|c|c|c|c|}
\hline Constant & $\begin{array}{l}0.544 \\
(1.457)\end{array}$ & $\begin{array}{l}0.224 \\
(1.420)\end{array}$ & $\begin{array}{l}0.492 \\
(1.454)\end{array}$ & $\begin{array}{l}-0.083 \\
(1.393)\end{array}$ & $\begin{array}{l}-0.175 \\
(1.410)\end{array}$ & $\begin{array}{l}0.345 \\
(1.446)\end{array}$ & $\begin{array}{l}0.361 \\
(1.407)\end{array}$ & $\begin{array}{l}0.151 \\
(1.477)\end{array}$ & $\begin{array}{l}1.902 \\
(1.667)\end{array}$ & $\begin{array}{l}-0.845 \\
(1.806)\end{array}$ & $\begin{array}{l}-0.611 \\
(1.538)\end{array}$ & $\begin{array}{l}-0.299 \\
(1.458)\end{array}$ \\
\hline
\end{tabular}


Table 8 - Financial Literacy, Risk Tolerance and Defaults on Other Loans

\begin{tabular}{|c|c|c|c|c|c|c|c|c|c|c|c|c|}
\hline & M1 & M2 & M3 & M4 & M5 & M6 & M7 & M8 & M9 & M10 & M11 & M12 \\
\hline Household Size & $\begin{array}{l}-1.369^{* *} \\
(0.545)\end{array}$ & $\begin{array}{l}-1.333^{* *} \\
(0.546)\end{array}$ & $\begin{array}{l}-1.197 * * \\
(0.540)\end{array}$ & $\begin{array}{l}-1.191 * * \\
(0.534)\end{array}$ & $\begin{array}{l}-1.166^{* *} \\
(0.525)\end{array}$ & $\begin{array}{l}-1.300 * * \\
(0.535)\end{array}$ & $\begin{array}{l}-1.408 * * \\
(0.558)\end{array}$ & $\begin{array}{l}-1.193 * * \\
(0.557)\end{array}$ & $\begin{array}{l}-1.320^{* *} \\
(0.525)\end{array}$ & $\begin{array}{l}-1.291 * * \\
(0.525)\end{array}$ & $\begin{array}{l}-1.332 * * \\
(0.525)\end{array}$ & $\begin{array}{l}-1.251 * * \\
(0.530)\end{array}$ \\
\hline Female: Dummy & $\begin{array}{l}0.608 \\
(0.603)\end{array}$ & $\begin{array}{l}0.735 \\
(0.596)\end{array}$ & $\begin{array}{l}0.535 \\
(0.598)\end{array}$ & $\begin{array}{l}0.584 \\
(0.614)\end{array}$ & $\begin{array}{l}0.635 \\
(0.581)\end{array}$ & $\begin{array}{l}0.722 \\
(0.577)\end{array}$ & $\begin{array}{l}0.761 \\
(0.594)\end{array}$ & $\begin{array}{l}0.422 \\
(0.609)\end{array}$ & $\begin{array}{l}0.869 \\
(0.568)\end{array}$ & $\begin{array}{l}0.851 \\
(0.561)\end{array}$ & $\begin{array}{l}0.843 \\
(0.564)\end{array}$ & $\begin{array}{l}0.877 \\
(0.567)\end{array}$ \\
\hline Age & $\begin{array}{l}0.561 \\
(0.388)\end{array}$ & $\begin{array}{l}0.536 \\
(0.389)\end{array}$ & $\begin{array}{l}0.431 \\
(0.385)\end{array}$ & $\begin{array}{l}0.518 \\
(0.392)\end{array}$ & $\begin{array}{l}0.612 \\
(0.383)\end{array}$ & $\begin{array}{l}0.588 \\
(0.395)\end{array}$ & $\begin{array}{l}0.541 \\
(0.385)\end{array}$ & $\begin{array}{l}0.466 \\
(0.385)\end{array}$ & $\begin{array}{l}0.648 \\
(0.398)\end{array}$ & $\begin{array}{l}0.645 \\
(0.397)\end{array}$ & $\begin{array}{l}0.628 \\
(0.397)\end{array}$ & $\begin{array}{l}0.629 \\
(0.399)\end{array}$ \\
\hline First Degree: Dummy & $\begin{array}{l}-0.172 \\
(0.727)\end{array}$ & $\begin{array}{l}-0.152 \\
(0.740)\end{array}$ & $\begin{array}{l}-0.387 \\
(0.749)\end{array}$ & $\begin{array}{l}-0.093 \\
(0.748)\end{array}$ & $\begin{array}{l}0.007 \\
(0.704)\end{array}$ & $\begin{array}{l}-0.128 \\
(0.724)\end{array}$ & $\begin{array}{l}-0.257 \\
(0.734)\end{array}$ & $\begin{array}{l}-0.121 \\
(0.747)\end{array}$ & $\begin{array}{l}0.081 \\
(0.716)\end{array}$ & $\begin{array}{l}0.044 \\
(0.711)\end{array}$ & $\begin{array}{l}-0.015 \\
(0.724)\end{array}$ & $\begin{array}{l}0.095 \\
(0.713)\end{array}$ \\
\hline $\begin{array}{l}\text { Higher National Diploma: } \\
\text { Dummy }\end{array}$ & $\begin{array}{l}-1.323 \\
(0.915)\end{array}$ & $\begin{array}{l}-0.933 \\
(0.842)\end{array}$ & $\begin{array}{l}-1.191 \\
(0.909)\end{array}$ & $\begin{array}{l}-1.235 \\
(0.916)\end{array}$ & $\begin{array}{l}-0.666 \\
(0.830)\end{array}$ & $\begin{array}{l}-0.746 \\
(0.829)\end{array}$ & $\begin{array}{l}-1.232 \\
(0.890)\end{array}$ & $\begin{array}{l}-0.836 \\
(0.878)\end{array}$ & $\begin{array}{l}-0.496 \\
(0.804)\end{array}$ & $\begin{array}{l}-0.484 \\
(0.800)\end{array}$ & $\begin{array}{l}-0.568 \\
(0.820)\end{array}$ & $\begin{array}{l}-0.448 \\
(0.803)\end{array}$ \\
\hline Self Employed & $\begin{array}{l}-2.177 * * \\
(0.964)\end{array}$ & $\begin{array}{l}-2.310 * * * \\
(0.861)\end{array}$ & $\begin{array}{l}-2.388 * * \\
(0.960)\end{array}$ & $\begin{array}{l}-2.743 * * * \\
(1.036)\end{array}$ & $\begin{array}{l}-2.169 * * \\
(0.863)\end{array}$ & $\begin{array}{l}-2.114 * * \\
(0.848)\end{array}$ & $\begin{array}{l}-1.985 * * \\
(0.867)\end{array}$ & $\begin{array}{l}-2.081 * * \\
(0.872)\end{array}$ & $\begin{array}{l}-2.040 * * \\
(0.814)\end{array}$ & $\begin{array}{l}-2.042 * * \\
(0.812)\end{array}$ & $\begin{array}{l}-1.999 * * \\
(0.821)\end{array}$ & $\begin{array}{l}-2.040 * * \\
(0.814)\end{array}$ \\
\hline Private Sector Employee & $\begin{array}{l}-1.768 * * \\
(0.698)\end{array}$ & $\begin{array}{l}-1.770^{* *} \\
(0.698)\end{array}$ & $\begin{array}{l}-1.732 * * \\
(0.695)\end{array}$ & $\begin{array}{l}-1.550^{* *} \\
(0.694)\end{array}$ & $\begin{array}{l}-1.522 * * \\
(0.658)\end{array}$ & $\begin{array}{l}-1.574 * * \\
(0.667)\end{array}$ & $\begin{array}{l}-1.735 * * \\
(0.692)\end{array}$ & $\begin{array}{l}-1.799 * * \\
(0.716)\end{array}$ & $\begin{array}{l}-1.524 \\
(0.662)\end{array}$ & $\begin{array}{l}-1.579 * * \\
(0.657)\end{array}$ & $\begin{array}{l}-1.502 * * \\
(0.666)\end{array}$ & $\begin{array}{l}-1.574 * * \\
(0.656)\end{array}$ \\
\hline Marital Status: Single & $\begin{array}{l}3.007 * * * \\
(0.997)\end{array}$ & $\begin{array}{l}2.116^{* *} \\
(0.954)\end{array}$ & $\begin{array}{l}2.792 * * * \\
(0.985)\end{array}$ & $\begin{array}{l}2.549 * * * \\
(0.947)\end{array}$ & $\begin{array}{l}2.727 * * * \\
(0.930)\end{array}$ & $\begin{array}{l}2.619 * * * \\
(0.925)\end{array}$ & $\begin{array}{l}2.501 * * * \\
(0.945)\end{array}$ & $\begin{array}{l}2.404 * * \\
(0.937)\end{array}$ & $\begin{array}{l}2.857 * * * \\
(0.911)\end{array}$ & $\begin{array}{l}2.800 * * * \\
(0.907)\end{array}$ & $\begin{array}{l}2.839 * * * \\
(0.909)\end{array}$ & $\begin{array}{l}2.739 * * * \\
(0.912)\end{array}$ \\
\hline $\begin{array}{l}\text { Knowledge of Need for } \\
\text { Emergency Funds: Dummy }\end{array}$ & $\begin{array}{l}2.907 * * \\
(1.174)\end{array}$ & & & & & & & & & & & \\
\hline $\begin{array}{l}\text { Ownership of Emergency } \\
\text { Fund: Dummy }\end{array}$ & & $\begin{array}{l}1.289 * * \\
(0.570)\end{array}$ & & & & & & & & & & \\
\hline $\begin{array}{l}\text { Knowledge of where to keep } \\
\text { emergency fund }\end{array}$ & & & $\begin{array}{l}1.991 * * \\
(0.776)\end{array}$ & & & & & & & & & \\
\hline $\begin{array}{l}\text { Knowledge of how to } \\
\text { calculate interest rates }\end{array}$ & & & & $\begin{array}{l}2.329 * * * \\
(0.819)\end{array}$ & & & & & & & & \\
\hline $\begin{array}{l}\text { Knowledge of how to set up } \\
\text { personal budgets }\end{array}$ & & & & & $\begin{array}{l}1.172 \\
(0.776)\end{array}$ & & & & & & & \\
\hline $\begin{array}{l}\text { Ownership of a personal } \\
\text { budget }\end{array}$ & & & & & & $\begin{array}{l}1.061^{*} \\
(0.626)\end{array}$ & & & & & & \\
\hline $\begin{array}{l}\text { Ownership of a household } \\
\text { budget }\end{array}$ & & & & & & & $\begin{array}{l}1.506^{* *} \\
(0.625)\end{array}$ & & & & & \\
\hline $\begin{array}{l}\text { Ability to track household } \\
\text { expenditure }\end{array}$ & & & & & & & & $\begin{array}{l}1.700^{* * *} \\
(0.583)\end{array}$ & & & & \\
\hline Percentage of housing budget & & & & & & & & & $\begin{array}{l}-0.016 \\
(0.027)\end{array}$ & & & \\
\hline Percentage of food budget & & & & & & & & & & $\begin{array}{l}-0.007 \\
(0.029)\end{array}$ & & \\
\hline Percentage of clothing budget & & & & & & & & & & & $\begin{array}{l}0.022 \\
(0.040)\end{array}$ & \\
\hline Description & & & & & & & & & & & & $\begin{array}{l}-0.146 \\
(0.273)\end{array}$ \\
\hline Constant & 1.238 & 0.972 & 1.394 & 0.827 & 0.694 & 0.926 & 1.173 & 0.917 & 1.374 & 1.143 & 0.475 & 1.122 \\
\hline
\end{tabular}


Table 9: Macroeconomic Performance, Credit Access Constraints and Previous Challenges Repaying Other Loans

\begin{tabular}{|c|c|c|c|c|c|c|c|c|c|c|}
\hline & M1 & M2 & M3 & M4 & M5 & M6 & M7 & M8 & M9 & M10 \\
\hline Household Size & $\begin{array}{l}-0.572 \\
(0.444)\end{array}$ & $\begin{array}{l}-0.588 \\
(0.444)\end{array}$ & $\begin{array}{l}-0.591 \\
(0.444)\end{array}$ & $\begin{array}{l}-0.556 \\
(0.448)\end{array}$ & $\begin{array}{l}-0.613 \\
(0.450)\end{array}$ & $\begin{array}{l}-0.754 \\
(0.469)\end{array}$ & $\begin{array}{l}-0.642 \\
(0.454)\end{array}$ & $\begin{array}{l}-0.447 \\
(0.458)\end{array}$ & $\begin{array}{l}-0.455 \\
(0.461)\end{array}$ & $\begin{array}{l}-0.565 \\
(0.460)\end{array}$ \\
\hline Female: Dummy & $\begin{array}{l}0.980 * * \\
(0.502)\end{array}$ & $\begin{array}{l}1.068^{* *} \\
(0.500)\end{array}$ & $\begin{array}{l}1.070^{* *} \\
(0.500)\end{array}$ & $\begin{array}{l}1.092 * * \\
(0.512)\end{array}$ & $\begin{array}{l}0.978 * * \\
(0.510)\end{array}$ & $\begin{array}{l}1.039^{* *} \\
(0.516)\end{array}$ & $\begin{array}{l}1.031 * * \\
(0.499)\end{array}$ & $\begin{array}{l}0.695 \\
(0.531)\end{array}$ & $\begin{array}{l}0.614 \\
(0.537)\end{array}$ & $\begin{array}{l}0.691 \\
(0.526)\end{array}$ \\
\hline Age & $\begin{array}{l}0.823 * * \\
(0.347)\end{array}$ & $\begin{array}{l}0.797 * * \\
(0.341)\end{array}$ & $\begin{array}{l}0.762 * * \\
(0.344)\end{array}$ & $\begin{array}{l}0.783 * * \\
(0.339)\end{array}$ & $\begin{array}{l}0.778 * * \\
(0.340)\end{array}$ & $\begin{array}{l}0.748^{* *} \\
(0.348)\end{array}$ & $\begin{array}{l}0.815^{* *} \\
(0.345)\end{array}$ & $\begin{array}{l}0.790^{* *} \\
(0.346)\end{array}$ & $\begin{array}{l}0.711^{* *} \\
(0.349)\end{array}$ & $\begin{array}{l}0.809 * * \\
(0.339)\end{array}$ \\
\hline First Degree: Dummy & $\begin{array}{l}-0.526 \\
(0.660)\end{array}$ & $\begin{array}{l}-0.475 \\
(0.655)\end{array}$ & $\begin{array}{l}-0.450 \\
(0.650)\end{array}$ & $\begin{array}{l}-0.458 \\
(0.650)\end{array}$ & $\begin{array}{l}-0.499 \\
(0.656)\end{array}$ & $\begin{array}{l}-0.655 \\
(0.694)\end{array}$ & $\begin{array}{l}-0.490 \\
(0.653)\end{array}$ & $\begin{array}{l}-0.450 \\
(0.659)\end{array}$ & $\begin{array}{l}-0.616 \\
(0.673)\end{array}$ & $\begin{array}{l}-0.513 \\
(0.664)\end{array}$ \\
\hline Higher National Diploma: Dummy & $\begin{array}{l}-0.045 \\
(0.767)\end{array}$ & $\begin{array}{l}0.040 \\
(0.756)\end{array}$ & $\begin{array}{l}0.058 \\
(0.753)\end{array}$ & $\begin{array}{l}0.072 \\
(0.752)\end{array}$ & $\begin{array}{l}0.046 \\
(0.754)\end{array}$ & $\begin{array}{l}-0.196 \\
(0.785)\end{array}$ & $\begin{array}{l}0.051 \\
(0.753)\end{array}$ & $\begin{array}{l}0.067 \\
(0.807)\end{array}$ & $\begin{array}{l}-0.392 \\
(0.829)\end{array}$ & $\begin{array}{l}-0.181 \\
(0.805)\end{array}$ \\
\hline Self Employed & $\begin{array}{l}-1.883 * * \\
(0.809)\end{array}$ & $\begin{array}{l}-2.148 * * * \\
(0.802)\end{array}$ & $\begin{array}{l}-1.969 \\
(0.794) * *\end{array}$ & $\begin{array}{l}-2.068 * * * \\
(0.786)\end{array}$ & $\begin{array}{l}-2.055^{* * * *} \\
(0.786)\end{array}$ & $\begin{array}{l}-2.170 * * * \\
(0.787)\end{array}$ & $\begin{array}{l}-2.106^{* * * *} \\
(0.789)\end{array}$ & $\begin{array}{l}-2.457 \\
(0.907)^{* * *}\end{array}$ & $\begin{array}{l}-2.169 * * \\
(0.893)\end{array}$ & $\begin{array}{l}-1.918^{* *} \\
(0.823)\end{array}$ \\
\hline Private Sector Employee & $\begin{array}{l}-0.879 \\
(0.652)\end{array}$ & $\begin{array}{l}-1.072 * \\
(0.588)\end{array}$ & $\begin{array}{l}-1.090^{*} \\
(0.590)\end{array}$ & $\begin{array}{l}-1.087^{*} \\
(0.590)\end{array}$ & $\begin{array}{l}-1.059^{*} \\
(0.594)\end{array}$ & $\begin{array}{l}-1.107^{*} \\
(0.623)\end{array}$ & $\begin{array}{l}-1.127^{*} \\
(0.593)\end{array}$ & $\begin{array}{l}-0.854 \\
(0.605)\end{array}$ & $\begin{array}{l}-1.128^{*} \\
(0.633)\end{array}$ & $\begin{array}{l}-1.140^{*} \\
(0.609)\end{array}$ \\
\hline Marital Status: Single & $\begin{array}{l}2.109 * * * \\
(0.650)\end{array}$ & $\begin{array}{l}2.198 * * * \\
(0.659)\end{array}$ & $\begin{array}{l}2.094 * * * \\
(0.661)\end{array}$ & $\begin{array}{l}2.136 * * * \\
(0.658)\end{array}$ & $\begin{array}{l}2.261 * * * \\
(0.680)\end{array}$ & $\begin{array}{l}2.458 * * * \\
(0.697)\end{array}$ & $\begin{array}{l}2.190 * * * \\
(0.659)\end{array}$ & $\begin{array}{l}2.232 * * * \\
(0.707)\end{array}$ & $\begin{array}{l}2.273 * * * \\
(0.729)\end{array}$ & $\begin{array}{l}2.080 * * * \\
(0.689)\end{array}$ \\
\hline Average Monthly Income & $\begin{array}{l}-0.215 \\
(0.266)\end{array}$ & & & & & & & & & \\
\hline Interest Rate & & $\begin{array}{l}-0.091 \\
(0.168)\end{array}$ & & & & & & & & \\
\hline Inflation Rate & & & $\begin{array}{l}0.138 \\
(0.176)\end{array}$ & & & & & & & \\
\hline Exchange Rate & & & & $\begin{array}{l}0.073 \\
(0.201)\end{array}$ & & & & & & \\
\hline National Growth Rate & & & & & $\begin{array}{l}-0.150 \\
(0.242)\end{array}$ & & & & & \\
\hline National Savings Rate & & & & & & $\begin{array}{l}-0.552 * * \\
(0.234)\end{array}$ & & & & \\
\hline Unemployment Rate & & & & & & & $\begin{array}{l}-0.130 \\
(0.176)\end{array}$ & & & \\
\hline Interest Rate Effects & & & & & & & & $\begin{array}{l}1.784 * * * \\
(0.639)\end{array}$ & & \\
\hline Collateral Security effects & & & & & & & & & $\begin{array}{l}2.614 * * * \\
(0.893)\end{array}$ & \\
\hline Loan Size Effects & & & & & & & & & & $\begin{array}{l}1.527 * * \\
(0.610)\end{array}$ \\
\hline Constant & $\begin{array}{l}-0.964 \\
(1.473)\end{array}$ & $\begin{array}{l}-1.217 \\
(1.416)\end{array}$ & $\begin{array}{l}-1.887 \\
(1.435)\end{array}$ & $\begin{array}{l}-1.808 \\
(1.600)\end{array}$ & $\begin{array}{l}-0.941 \\
(1.589)\end{array}$ & $\begin{array}{l}0.764 \\
(1.672)\end{array}$ & $\begin{array}{l}-1.013 \\
(1.468)\end{array}$ & $\begin{array}{l}-1.964 \\
(1.387)\end{array}$ & $\begin{array}{l}-1.510 \\
(1.394)\end{array}$ & $\begin{array}{l}-1.686 \\
(1.378) \\
\end{array}$ \\
\hline
\end{tabular}


Table 10 - Macroeconomic Performance, Credit Access Constraints and Defaults on Other Loans

\begin{tabular}{|c|c|c|c|c|c|c|c|c|c|c|}
\hline & M1 & M2 & M3 & M4 & M5 & M6 & M7 & M8 & M9 & M10 \\
\hline Household Size & \begin{tabular}{|c|}
-0.354 \\
$(0.593)$ \\
\end{tabular} & $\begin{array}{l}-0.312 \\
(0.583) \\
\end{array}$ & $\begin{array}{l}-0.345 \\
(0.584) \\
\end{array}$ & \begin{tabular}{|l|}
-0.291 \\
$(0.589)$ \\
\end{tabular} & \begin{tabular}{|l|}
-0.318 \\
$(0.594)$ \\
\end{tabular} & \begin{tabular}{|l}
-0.362 \\
$(0.590)$ \\
\end{tabular} & $\begin{array}{l}-0.309 \\
(0.588) \\
\end{array}$ & $\begin{array}{l}-0.216 \\
(0.573) \\
\end{array}$ & $\begin{array}{l}-0.271 \\
(0.582) \\
\end{array}$ & $\begin{array}{l}-0.304 \\
(0.571) \\
\end{array}$ \\
\hline Female: Dummy & $\begin{array}{l}1.482 * * \\
(0.648)\end{array}$ & $\begin{array}{l}1.435^{* *} \\
(0.641)\end{array}$ & $\begin{array}{l}1.446^{* *} \\
(0.646)\end{array}$ & $\begin{array}{l}1.576^{* *} \\
(0.672)\end{array}$ & $\begin{array}{l}1.578^{* *} \\
(0.680)\end{array}$ & $\begin{array}{l}1.416^{* *} \\
(0.647) \\
\end{array}$ & $\begin{array}{l}1.434 * * \\
(0.644)\end{array}$ & $\begin{array}{l}1.197 * \\
(0.662)\end{array}$ & $\begin{array}{l}1.330^{* *} \\
(0.665)\end{array}$ & $\begin{array}{l}1.186^{*} \\
(0.662)\end{array}$ \\
\hline Age & $\begin{array}{l}-0.121 \\
(0.379) \\
\end{array}$ & $\begin{array}{l}-0.021 \\
(0.377) \\
\end{array}$ & $\begin{array}{l}-0.071 \\
(0.383) \\
\end{array}$ & \begin{tabular}{|l}
-0.041 \\
$(0.376)$ \\
\end{tabular} & $\begin{array}{l}-0.022 \\
(0.377) \\
\end{array}$ & \begin{tabular}{|c|}
-0.053 \\
$(0.378)$ \\
\end{tabular} & $\begin{array}{l}-0.027 \\
(0.378) \\
\end{array}$ & $\begin{array}{l}-0.056 \\
(0.372) \\
\end{array}$ & $\begin{array}{l}-0.054 \\
(0.377) \\
\end{array}$ & $\begin{array}{l}-0.005 \\
(0.373) \\
\end{array}$ \\
\hline First Degree: Dummy & $\begin{array}{l}-0.474 \\
(0.864) \\
\end{array}$ & $\begin{array}{l}-0.653 \\
(0.862) \\
\end{array}$ & $\begin{array}{l}-0.646 \\
(0.875) \\
\end{array}$ & $\begin{array}{l}-0.610 \\
(0.874) \\
\end{array}$ & $\begin{array}{l}-0.586 \\
(0.871) \\
\end{array}$ & $\begin{array}{l}-0.779 \\
(0.889) \\
\end{array}$ & $\begin{array}{l}-0.650 \\
(0.864) \\
\end{array}$ & $\begin{array}{l}-0.569 \\
(0.853) \\
\end{array}$ & $\begin{array}{l}-0.651 \\
(0.858) \\
\end{array}$ & $\begin{array}{l}-0.650 \\
(0.846) \\
\end{array}$ \\
\hline Higher National Diploma: Dummy & $\begin{array}{l}-0.435 \\
(0.939) \\
\end{array}$ & $\begin{array}{l}-0.633 \\
(0.929) \\
\end{array}$ & $\begin{array}{l}-0.609 \\
(0.944)\end{array}$ & $\begin{array}{l}-0.572 \\
(0.945) \\
\end{array}$ & $\begin{array}{l}-0.611 \\
(0.939)\end{array}$ & $\begin{array}{l}-0.811 \\
(0.969)\end{array}$ & $\begin{array}{l}-0.629 \\
(0.933)\end{array}$ & $\begin{array}{l}-0.516 \\
(0.941)\end{array}$ & $\begin{array}{l}-0.685 \\
(0.938) \\
\end{array}$ & $\begin{array}{l}-0.616 \\
(0.939)\end{array}$ \\
\hline Self Employed & $\begin{array}{l}-1.749^{* *} \\
(0.841)\end{array}$ & $\begin{array}{l}-1.493^{*} \\
(0.809) \\
\end{array}$ & $\begin{array}{l}-1.371^{*} \\
(0.810) \\
\end{array}$ & $\begin{array}{l}-1.481^{*} \\
(0.809) \\
\end{array}$ & $\begin{array}{l}-1.563^{*} \\
(0.815) \\
\end{array}$ & $\begin{array}{l}-1.482^{*} \\
(0.799) \\
\end{array}$ & $\begin{array}{l}-1.478^{*} \\
(0.798) \\
\end{array}$ & $\begin{array}{l}-1.453^{*} \\
(0.832) \\
\end{array}$ & $\begin{array}{l}-1.401) \\
(0.816) \\
\end{array}$ & \begin{tabular}{|l}
-1.287 \\
$(0.838)$ \\
\end{tabular} \\
\hline Private Sector Employee & $\begin{array}{l}-1.406^{*} \\
(0.777) \\
\end{array}$ & $\begin{array}{l}-0.987 \\
(0.687) \\
\end{array}$ & $\begin{array}{l}-0.934 \\
(0.693) \\
\end{array}$ & $\begin{array}{l}-0.947 \\
(0.684) \\
\end{array}$ & $\begin{array}{l}-1.119 \\
(0.705) \\
\end{array}$ & $\begin{array}{l}-0.897 \\
(0.696) \\
\end{array}$ & $\begin{array}{l}-0.993 \\
(0.686) \\
\end{array}$ & $\begin{array}{l}-0.808 \\
(0.693) \\
\end{array}$ & $\begin{array}{l}-0.948 \\
(0.689) \\
\end{array}$ & $\begin{array}{l}-1.012 \\
(0.700) \\
\end{array}$ \\
\hline Marital Status: Single & $\begin{array}{l}0.535 \\
(0.759) \\
\end{array}$ & $\begin{array}{l}0.461 \\
(0.743)\end{array}$ & $\begin{array}{l}0.349 \\
(0.755)\end{array}$ & $\begin{array}{l}0.313 \\
(0.752)\end{array}$ & $\begin{array}{l}0.332 \\
(0.752)\end{array}$ & $\begin{array}{l}0.533 \\
(0.754)\end{array}$ & $\begin{array}{l}0.454 \\
(0.741)\end{array}$ & $\begin{array}{l}0.345 \\
(0.755)\end{array}$ & $\begin{array}{l}0.419 \\
(0.749)\end{array}$ & $\begin{array}{l}0.348 \\
(0.764)\end{array}$ \\
\hline Average Monthly Income & $\begin{array}{l}0.389 \\
(0.321) \\
\end{array}$ & & & & & & & & & \\
\hline Interest Rate & & \begin{tabular}{|c|}
-0.023 \\
$(0.193)$ \\
\end{tabular} & & & & & & & & \\
\hline Inflation Rate & & & $\begin{array}{l}0.180 \\
(0.224)\end{array}$ & & & & & & & \\
\hline Exchange Rate & & & & $\begin{array}{l}0.235 \\
(0.229) \\
\end{array}$ & & & & & & \\
\hline National Growth Rate & & & & & $\begin{array}{l}0.235 \\
(0.295) \\
\end{array}$ & & & & & \\
\hline National Savings Rate & & & & & & $\begin{array}{l}-0.236 \\
(0.274)\end{array}$ & & & & \\
\hline Unemployment Rate & & & & & & & $\begin{array}{l}0.009 \\
(0.209) \\
\end{array}$ & & & \\
\hline Interest Rate Effects & & & & & & & & $\begin{array}{l}1.299 \\
(1.061) \\
\end{array}$ & & \\
\hline Collateral Security effects & & & & & & & & & $\begin{array}{l}0.430 \\
(0.845) \\
\end{array}$ & \\
\hline
\end{tabular}




\begin{tabular}{|l|l|l|l|l|l|l|l|l|l|l|}
\hline Loan Size Effects & & & & & & & & & & $\begin{array}{l}1.501 \\
(1.660)\end{array}$ \\
\hline Constant & 1.501 & 2.423 & 1.954 & 1.531 & 1.592 & 3.371 & 2.322 & 2.109 & 2.338 & 2.149 \\
& $(1.813)$ & $(1.779)$ & $(1.776)$ & $(1.868)$ & $(1.954)$ & $(2.087)$ & $(1.858)$ & $(1.657)$ & $(1.675)$ & $(1.660)$ \\
\hline
\end{tabular}


Table 11 - Macroeconomic Performance, Credit Access Constraints and Previous Challenges Repaying Mortgages

\begin{tabular}{|c|c|c|c|c|c|c|c|c|c|c|}
\hline & M1 & M2 & M3 & M4 & M5 & M6 & M7 & M8 & M9 & M10 \\
\hline Household Size & \begin{tabular}{|c|}
$-0.864^{*}$ \\
$(0.471)$
\end{tabular} & $\begin{array}{l}-0.853^{*} \\
(0.472)\end{array}$ & $\begin{array}{l}-0.880^{*} \\
(0.476)\end{array}$ & $\begin{array}{l}-0.748 \\
(0.486)\end{array}$ & $\begin{array}{l}-0.826^{*} \\
(0.473)\end{array}$ & $\begin{array}{l}-0.952 * * \\
(0.483)\end{array}$ & $\begin{array}{l}-0.908^{*} \\
(0.478)\end{array}$ & $\begin{array}{l}-0.729 \\
(0.484) \\
\end{array}$ & \begin{tabular}{|l|}
-0.760 \\
$(0.481)$
\end{tabular} & \begin{tabular}{|c|}
$-0.848^{*}$ \\
$(0.478)$
\end{tabular} \\
\hline Female: Dummy & $\begin{array}{l}0.248 \\
(0.511)\end{array}$ & $\begin{array}{l}0.192 \\
(0.506)\end{array}$ & $\begin{array}{l}0.234 \\
(0.509)\end{array}$ & $\begin{array}{l}0.424 \\
(0.530)\end{array}$ & $\begin{array}{l}0.274 \\
(0.522)\end{array}$ & $\begin{array}{l}0.143 \\
(0.511)\end{array}$ & $\begin{array}{l}0.188 \\
(0.505)\end{array}$ & $\begin{array}{l}-0.236 \\
(0.547)\end{array}$ & $\begin{array}{l}-0.227 \\
(0.542)\end{array}$ & $\begin{array}{l}-0.077 \\
(0.532)\end{array}$ \\
\hline Age & $\begin{array}{l}0.580 \\
(0.367)\end{array}$ & $\begin{array}{l}0.576 \\
(0.366)\end{array}$ & $\begin{array}{l}0.551 \\
(0.370)\end{array}$ & $\begin{array}{l}0.595^{*} \\
(0.361)\end{array}$ & $\begin{array}{l}0.606^{*} \\
(0.364)\end{array}$ & $\begin{array}{l}0.577 \\
(0.368)\end{array}$ & $\begin{array}{l}0.642 * \\
(0.371)\end{array}$ & $\begin{array}{l}0.581 \\
(0.362)\end{array}$ & $\begin{array}{l}0.488 \\
(0.360)\end{array}$ & $\begin{array}{l}0.601 * \\
(0.358)\end{array}$ \\
\hline First Degree: Dummy & $\begin{array}{l}0.178 \\
(0.673)\end{array}$ & $\begin{array}{l}0.168 \\
(0.673)\end{array}$ & $\begin{array}{l}0.192 \\
(0.676)\end{array}$ & $\begin{array}{l}0.211 \\
(0.686)\end{array}$ & $\begin{array}{l}0.174 \\
(0.671)\end{array}$ & $\begin{array}{l}0.098 \\
(0.684)\end{array}$ & $\begin{array}{l}0.138 \\
(0.670)\end{array}$ & $\begin{array}{l}0.183 \\
(0.682)\end{array}$ & $\begin{array}{l}0.033 \\
(0.680)\end{array}$ & $\begin{array}{l}0.114 \\
(0.674)\end{array}$ \\
\hline Higher National Diploma: Dummy & $\begin{array}{l}-0.026 \\
(0.773)\end{array}$ & $\begin{array}{l}-0.045 \\
(0.773)\end{array}$ & $\begin{array}{l}-0.055 \\
(0.777)\end{array}$ & $\begin{array}{l}-0.059 \\
(0.783)\end{array}$ & $\begin{array}{l}-0.062 \\
(0.768)\end{array}$ & $\begin{array}{l}-0.183 \\
(0.779)\end{array}$ & $\begin{array}{l}-0.055 \\
(0.769)\end{array}$ & $\begin{array}{l}-0.146 \\
(0.825)\end{array}$ & $\begin{array}{l}-0.521 \\
(0.826)\end{array}$ & $\begin{array}{l}-0.320 \\
(0.805)\end{array}$ \\
\hline Self Employed & $\begin{array}{l}-2.408^{* * *} \\
(0.837)\end{array}$ & $\begin{array}{l}-2.219^{* * *} \\
(0.801)\end{array}$ & $\begin{array}{l}-2.152 * * * \\
(0.798)\end{array}$ & $\begin{array}{l}-2.350^{* * *} \\
(0.827)\end{array}$ & $\begin{array}{l}-2.331 * * * \\
(0.805)\end{array}$ & $\begin{array}{l}-2.387 * * * \\
(0.799)\end{array}$ & $\begin{array}{l}-2.344 * * * \\
(0.808)\end{array}$ & $\begin{array}{l}-2.844 * * * \\
(0.985)\end{array}$ & $\begin{array}{l}-2.472 * * * \\
(0.885)\end{array}$ & $\begin{array}{l}-2.210^{* * * *} \\
(0.815)\end{array}$ \\
\hline Private Sector Employee & $\begin{array}{l}-1.455^{* *} \\
(0.671)\end{array}$ & $\begin{array}{l}-1.400 * * \\
(0.608)\end{array}$ & $\begin{array}{l}-1.269 * * \\
(0.604)\end{array}$ & $\begin{array}{l}-1.202 * * \\
(0.603)\end{array}$ & $\begin{array}{l}-1.373 * * \\
(0.602)\end{array}$ & $\begin{array}{l}-1.294^{* *} \\
(0.611)\end{array}$ & $\begin{array}{l}-1.352^{* *} \\
(0.602)\end{array}$ & $\begin{array}{l}-1.083^{*} \\
(0.614)\end{array}$ & $\begin{array}{l}-1.334^{* *} \\
(0.624)\end{array}$ & $\begin{array}{l}-1.365^{* *} \\
(0.610)\end{array}$ \\
\hline Marital Status: Single & $\begin{array}{l}2.148^{* * *} \\
(0.727)\end{array}$ & $\begin{array}{l}2.050^{* * *} \\
(0.720)\end{array}$ & $\begin{array}{l}1.959 * * * \\
(0.729)\end{array}$ & $\begin{array}{l}1.964 * * * \\
(0.728)\end{array}$ & $\begin{array}{l}2.044 * * * \\
(0.730)\end{array}$ & $\begin{array}{l}2.263 * * * \\
(0.733)\end{array}$ & $\begin{array}{l}2.132 * * * \\
(0.717)\end{array}$ & $\begin{array}{l}2.188 * * * \\
(0.792)\end{array}$ & $\begin{array}{l}2.161 * * * \\
(0.783)\end{array}$ & $\begin{array}{l}2.059 * * * \\
(0.739)\end{array}$ \\
\hline Average Monthly Income & $\begin{array}{l}0.111 \\
(0.268)\end{array}$ & & & & & & & & & \\
\hline Interest Rate & & $\begin{array}{l}0.169 \\
(0.168)\end{array}$ & & & & & & & & \\
\hline Inflation Rate & & & $\begin{array}{l}0.258 \\
(0.184)\end{array}$ & & & & & & & \\
\hline Exchange Rate & & & & $\begin{array}{l}0.411 * * \\
(0.209)\end{array}$ & & & & & & \\
\hline National Growth Rate & & & & & $\begin{array}{l}0.114 \\
(0.251)\end{array}$ & & & & & \\
\hline National Savings Rate & & & & & & $\begin{array}{l}-0.348 \\
(0.223) \\
\end{array}$ & & & & \\
\hline Unemployment Rate & & & & & & & $\begin{array}{l}-0.118 \\
(0.181)\end{array}$ & & & \\
\hline Interest Rate Effects & & & & & & & & $\begin{array}{l}2.218^{* * *} \\
(0.833) \\
\end{array}$ & & \\
\hline Collateral Security effects & & & & & & & & & $\begin{array}{l}2.291^{* *} \\
(0.928) \\
\end{array}$ & \\
\hline Loan Size Effects & & & & & & & & & & $\begin{array}{l}1.033 * \\
(0.581)\end{array}$ \\
\hline Constant & $\begin{array}{l}-0.088 \\
(1.493) \\
\end{array}$ & $\begin{array}{l}-0.333 \\
(1.462) \\
\end{array}$ & \begin{tabular}{|l}
-0.494 \\
$(1.461)$ \\
\end{tabular} & $\begin{array}{l}-1.449 \\
(1.625) \\
\end{array}$ & $\begin{array}{l}-0.252 \\
(1.643) \\
\end{array}$ & $\begin{array}{l}1.589 \\
(1.672)\end{array}$ & $\begin{array}{l}0.578 \\
(1.511) \\
\end{array}$ & $\begin{array}{l}-0.152 \\
(1.397) \\
\end{array}$ & $\begin{array}{l}0.388 \\
(1.408) \\
\end{array}$ & $\begin{array}{l}0.139 \\
(1.384)\end{array}$ \\
\hline
\end{tabular}


Table 12 - Macroeconomic Performance, Credit Access Constraints and Defaults on Other Loans

\begin{tabular}{|c|c|c|c|c|c|c|c|c|c|c|}
\hline & M1 & M2 & M3 & M4 & M5 & M6 & M7 & M8 & M9 & M10 \\
\hline Household Size & $\begin{array}{l}-1.318^{* *} \\
(0.526)\end{array}$ & $\begin{array}{l}-1.325 * * \\
(0.532) \\
\end{array}$ & $\begin{array}{l}-1.371 * * \\
(0540)\end{array}$ & $\begin{array}{l}-1.257 * * \\
(0.551) \\
\end{array}$ & $\begin{array}{l}-1.297 * * \\
(0.525)\end{array}$ & $\begin{array}{l}-1.426^{* * *} \\
(0.540)\end{array}$ & $\begin{array}{l}1.336 * * \\
(0.528)\end{array}$ & $\begin{array}{l}-1.192 * * \\
(0524)\end{array}$ & $\begin{array}{l}-1.195 * * \\
(0.523)\end{array}$ & $\begin{array}{l}-1.304 * * \\
(0.532)\end{array}$ \\
\hline Female: Dummy & $\begin{array}{l}0.885 \\
(0.571) \\
\end{array}$ & $\begin{array}{l}0.864 \\
(0.573) \\
\end{array}$ & $\begin{array}{l}0.919 \\
(0576)\end{array}$ & $\begin{array}{l}1.164 * * \\
(0.610)\end{array}$ & $\begin{array}{l}0.882 \\
(0.585) \\
\end{array}$ & $\begin{array}{l}0.806 \\
(0.575) \\
\end{array}$ & $\begin{array}{l}0.840 \\
(0.565)\end{array}$ & $\begin{array}{l}0.598 \\
(0.584)\end{array}$ & $\begin{array}{l}0.579 \\
(0.582) \\
\end{array}$ & $\begin{array}{l}0.593 \\
(0.588) \\
\end{array}$ \\
\hline Age & $\begin{array}{l}0.633 \\
(0.400)\end{array}$ & $\begin{array}{l}0.590 \\
(0.399)\end{array}$ & $\begin{array}{l}0.558 \\
(0.404)\end{array}$ & $\begin{array}{l}0.631 \\
(0.394)\end{array}$ & $\begin{array}{l}0.650 \\
(0.397)\end{array}$ & $\begin{array}{l}0.609 \\
(0.401)\end{array}$ & $\begin{array}{l}0.679 \\
(0.407)\end{array}$ & $\begin{array}{l}0.582 \\
(0.386)\end{array}$ & $\begin{array}{l}0.511 \\
(0.399)\end{array}$ & $\begin{array}{l}0.622 \\
(0.388) \\
\end{array}$ \\
\hline First Degree: Dummy & $\begin{array}{l}0.087 \\
(0.712) \\
\end{array}$ & $\begin{array}{l}0.107 \\
(0.721) \\
\end{array}$ & $\begin{array}{l}0.119 \\
(0.720)\end{array}$ & $\begin{array}{l}0.132 \\
(0.732) \\
\end{array}$ & $\begin{array}{l}0.073 \\
(0.712) \\
\end{array}$ & $\begin{array}{l}-0.014 \\
(0.737) \\
\end{array}$ & $\begin{array}{l}0.060 \\
(0.711) \\
\end{array}$ & $\begin{array}{l}0.117 \\
(0.704) \\
\end{array}$ & $\begin{array}{l}-0.030 \\
(0.708) \\
\end{array}$ & $\begin{array}{l}-0.005 \\
(0.708) \\
\end{array}$ \\
\hline Higher National Diploma: Dummy & $\begin{array}{l}-0.452 \\
(0.800)\end{array}$ & $\begin{array}{l}-0.425 \\
(0.811) \\
\end{array}$ & $\begin{array}{l}-0.442 \\
(0.816) \\
\end{array}$ & \begin{tabular}{|l}
-0.499 \\
$(0.823)$
\end{tabular} & $\begin{array}{l}-0.474 \\
(0.799) \\
\end{array}$ & $\begin{array}{l}-0.619 \\
(0.822) \\
\end{array}$ & $\begin{array}{l}-0.462 \\
(0.799) \\
\end{array}$ & $\begin{array}{l}-0.447 \\
(0.825) \\
\end{array}$ & $\begin{array}{l}-0.734 \\
(0.831) \\
\end{array}$ & $\begin{array}{l}-0.720 \\
(0.842) \\
\end{array}$ \\
\hline Self Employed & $\begin{array}{l}-2.131 * * \\
(0.855)\end{array}$ & $\begin{array}{l}-1.923 * * * \\
0.810)\end{array}$ & $\begin{array}{l}-1.905^{* *} \\
(0.811)\end{array}$ & $\begin{array}{l}-2.112 * * \\
(0.861)\end{array}$ & $\begin{array}{l}-2.053^{* *} \\
(0.812)\end{array}$ & $\begin{array}{l}-2.169^{* * *} \\
(0.815)\end{array}$ & $\begin{array}{l}-2.055^{* *} \\
(0.812)\end{array}$ & $\begin{array}{l}-2.195 * * \\
(0.896)\end{array}$ & $\begin{array}{l}-2.059^{* *} \\
(0.860)\end{array}$ & $\begin{array}{l}-1.981 * * \\
(0.856)\end{array}$ \\
\hline Private Sector Employee & $\begin{array}{l}-1.683 * * \\
(0.740)\end{array}$ & $\begin{array}{l}-1.710^{* *} \\
(0.689)\end{array}$ & $\begin{array}{l}-1.516^{* *} \\
(0.677)\end{array}$ & $\begin{array}{l}-1.463 * * \\
(0.668)\end{array}$ & $\begin{array}{l}-1.597 * * \\
(0.667)\end{array}$ & $\begin{array}{l}-1.504 * * \\
(0.684)\end{array}$ & $\begin{array}{l}-1.582 * * \\
(0.660)\end{array}$ & $\begin{array}{l}-1.349^{* *} \\
(0.664)\end{array}$ & $\begin{array}{l}-1.517 * * \\
(0.663)\end{array}$ & $\begin{array}{l}-1.636^{* *} \\
(0.678)\end{array}$ \\
\hline Marital Status: Single & $\begin{array}{l}2.858 * * * \\
(0.920)\end{array}$ & $\begin{array}{l}2.724 * * * \\
(0.909)\end{array}$ & $\begin{array}{l}2.628 * * * \\
(0.922)\end{array}$ & $\begin{array}{l}2.669 * * * \\
(0.921)\end{array}$ & $\begin{array}{l}2.785 * * * \\
(0.922)\end{array}$ & $\begin{array}{l}3.017 * * * \\
(0.927)\end{array}$ & $\begin{array}{l}2.825 * * * \\
(0.906)\end{array}$ & $\begin{array}{l}2.799 * * * \\
(0.934)\end{array}$ & $\begin{array}{l}2.810 * * * \\
(0.934)\end{array}$ & $\begin{array}{l}2.818^{* * * *} \\
(0.939)\end{array}$ \\
\hline Average Monthly Income & $\begin{array}{l}0.090 \\
(0.280)\end{array}$ & & & & & & & & & \\
\hline Interest Rate & & $\begin{array}{l}0.279 \\
(0.182) \\
\end{array}$ & & & & & & & & \\
\hline Inflation Rate & & & $\begin{array}{l}0.343 * \\
(0.201)\end{array}$ & & & & & & & \\
\hline Exchange Rate & & & & $\begin{array}{l}0.484 * * \\
(0.225)\end{array}$ & & & & & & \\
\hline National Growth Rate & & & & & $\begin{array}{l}0.047 \\
(0.281) \\
\end{array}$ & & & & & \\
\hline National Savings Rate & & & & & & $\begin{array}{l}-0.439 * \\
(0.245)\end{array}$ & & & & \\
\hline Unemployment Rate & & & & & & & $\begin{array}{l}-0.075 \\
(0.189) \\
\end{array}$ & & & \\
\hline Interest Rate Effects & & & & & & & & $\begin{array}{l}1.462 * * \\
(0.793)\end{array}$ & & \\
\hline
\end{tabular}




\begin{tabular}{|l|l|l|l|l|l|l|l|l|l|l|}
\hline Collateral Security effects & & & & & & & & & $\begin{array}{l}1.577^{*} \\
(0.884)\end{array}$ & \\
\hline Loan Size Effects & & & & & & & & & & $1.267^{*}$ \\
& & & & & & & & & & \\
$(0.685)$
\end{tabular}


